\title{
DOES THE PROCYCLICALITY OF CAPITAL REQUIREMENTS AFFECT FINANCIAL STABILITY IN CEMAC?
}

\author{
Djimoudjiel Djekonbé ${ }^{*}{ }^{凶}$, Ningaye Paul ${ }^{2}$, Nafé Daba ${ }^{3}$ \\ ${ }^{*} 1,2$ University of Dschang_Dschang School of Economics and Management, Cameroon \\ ${ }^{3}$ Bank of Central African States (BEAC), Cameroon
}

DOI: https://doi.org/10.29121/granthaalayah.v8.i7.2020.514

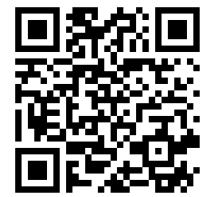

Article Type: Research Article

Article Citation: Djimoudjiel Djekonbé, Ningaye Paul, and Nafé Daba. (2020). DOES THE PROCYCLICALITY OF CAPITAL REQUIREMENTS AFFECT FINANCIAL STABILITY IN CEMAC?. International Journal of Research GRANTHAALAYAH, 8(7), 17-37. https://doi.org/10.29121/granthaa layah.v8.i7.2020.514

Received Date: 17 June 2020

Accepted Date: 24 July 2020

Keywords:

Capital Procyclicality

Financial Stability

Bank Profitability

CEMAC

SVAR

Jel Code: G32; E58; E31; 055

\begin{abstract}
The objective of this article is to analyze the effects of procyclical variations of the capital requirements on financial stability in the CEMAC 1. In order to achieve this objective, we have specified and estimated a panel VAR model using the structural factorization method on quarterly Central Bank data over the period 2006-2017. Firstly, the results show that procyclical capital adjustments in the CEMAC region lead to short-term financial instability through the contraction of credit to the private sector. Secondly, despite the low level of financial development, the effects maintained by the adjustment of monetary policy instruments in the short term remain significant on price stability. Finally, in the long term, the procyclicality of regulatory capital makes it possible to revive economic activity and guarantee financial stability. These results lead us to recommend the adoption of a more discretionary monetary policy so as to make more procyclical the capital requirement.
\end{abstract}

\section{INTRODUCTION}

The procyclicality of capital is understood in the context of a joint revaluation following a phase of economic expansion or a positive improvement of a given indicator (Tery, 2009). Interrogations around the procyclicality of bank capital from a regulatory point of view (or from a general point of view regarding the adjustment of the capital base in a cyclical context) became more pronounced after 1988. Period of the adoption of the Cooke ratio under the auspices of the Basel Committee on Banking Supervision (BCBS). As a result, several banks saw their capital (including profits) negatively affected because they set aside provisions for credit losses during periods of recession. In contrast, the economic downturn of 2000 showed a certain absence of procyclicality of the capital requirements, unlike the periods following the adoption of the Basel II ratio (Berenger and Teiletche, 2003). Capital under Basel II,

\footnotetext{
${ }^{1}$ Economic Community of Central African States comprising Cameroon, Central African Republic, Chad, Congo, Gabon and Equatorial Guinea.

(C) 2020 The Author(s). This is an open access article distributed under the terms of the Creative Commons Attribution License, which permits unrestricted use, distribution, and reproduction in any medium, provided the original author and source are credited. 
on the other hand, was considered more procyclical given the development of risk weighting (determination) methods under the standard and probabilistic approach. Indeed, capital (equity or core capital) becomes procyclical when it is adjusted upwards in a situation of increased risks or default losses (Estrella, 2004; Repullo et al., 2010). The subprime crisis of 2007 marked a decisive turning point in terms of the importance of the tradeoff between the pro or countercyclical adjustment of risk-covering capital in a recession or crisis phase. The angular point was the volatility of capital under the internal and standard weighting approaches. From the first quarters of 2007 to the last quarters of 2010, CEMAC banks adjusted their capital jointly and procyclically. While most research (Garabiol, 2005; Rabell et al., 2005; Repullo et al., 2010) suggests that bank capital becomes procyclical in periods of recession, it is clear that, in view of the recent oil shocks, the capital of CEMAC banks is moving upwards. Indeed, this link remains only a hypothesis insofar as Mitchell (1998) finds that procyclical adjustment depends on the level of financial development. However, in extension, the conclusions of Blum (1999) Berenger and Teiletche (2003) announce mixed cyclical adjustments in a given context of bank concentration. A readjustment of bank capital or equity implies a favorable market structure to allow banks to maximise their rents.

In a context of excess liquidity (Avom and Eyeffa, 2007), the CEMAC banking market reports a highly concentrated banking system (COBAC, 2010). The Cameroonian and Chadian banking markets have the lowest concentration indices (17.7\% and 17.5\% respectively), followed by Gabon and Congo (26.8\% and 28.5\%). The Central African Republic and Equatorial Guinea, for their part, have purely concentrated banking markets $(34.6 \%$ and 39.6\% consecutively) expressing weak banking competition (COBAC, 2010; COBAC, 2016). Combined with the recent recession and a low level of financial development, banks in the sub region are undergoing procyclical adjustments. As of 2014, CEMAC banks were barely able to meet capital adequacy standards ${ }^{2} .62 \%$ (32 of them) comply with the minimum capital requirement (10 billion) in 2014 and 44\% (23 out of 52) of banks are in compliance with capital adequacy standards (BEAC, 2016). That is to say, a procyclical adjustment of capital. The increase in share capital applied in 2009 following the 2007 crisis had previously led to a procyclical trend in regulatory capital. Controversially, bank deposits fell from 2015 (CFAF 1115 billion to 1071 billion) combined with reductions in mandatory reserves by $58.2 \%$ to reach 447 billion in 2016 (BEAC, 2018). At the same time, the central bank had to readjust its key rate downwards in order to revive the various economies and adjust a consequent financial stability (Bikai and Essiane, 2017).

The European Central Bank (ECB, 2016) states that, in view of the adverse effects of the 2007 crisis, the management of financial instability phenomena must be subject to constant change. Developments in bank stress tests and coordination of monetary and prudential policy instruments are the recommended financial stabilization alternatives. The introduction of new standards (public debt and foreign exchange reserve management) following the subprime crisis (Basel III) in 2007, requires banks to have a surplus, known as a buffer or capital buffer, in addition to regulatory capital. Surplus is considered as a guarantee of liquidity and risk response situations specific to banks (Grace et al., 2011).

This article aims to highlight the effects of procyclical variations in bank capital requirements on financial stability in the CEMAC region. In order to achieve this objective, it will first present the theoretical and empirical links between capital procyclicality and financial stability. Secondly, it will analyze the stylized facts between bank capitalization and the monetary policy instrument ensuring financial stability. The third part will propose a methodological approach to analyze the different effects of regulatory capital procyclicality shocks on financial stability. The various results and interpretations presented in the fourth part will be followed by a conclusion and recommendations.

\section{LITERATURE REVIEW}

\subsection{THEORETICAL APPROACHES}

The Schumpeterian analyses of 1917 based on capitalist money and the microeconomic foundations of banking made it possible to orient the role of banks in economic cycles accordingly. Indeed, these approaches derive from the foundations of the Austrians' theory of the economic cycle of 1912, from technological innovations as a

\footnotetext{
${ }^{2}$ In compliance with the accounting standards governing banking activity in CEMAC, several reports have been submitted to the banks with the aim of establishing a "sound" financial system. These include compliance with reports on liquidity, transformation, coverage of fixed assets, etc... 
consequence of financial instability. The cyclical tendencies of economies following exogenous shocks thus lead to similarly cyclical adjustments in the behavior of banks (Schwartz S., 1987). In a context of financial instability, procyclical adjustments respond to a process of recapitalization and default management. In line with public choice theory, recapitalization makes it possible to meet the demands of lender funds for the purpose of improving consumer welfare (Stern and Feldman, 2004). Moreover, the findings of Bain's (1957) Structure-BehaviorPerformance (SCP) models have subsequently ruled that an improvement in consumer welfare depends on the prevailing level of bank concentration. Demsetz's contradiction in 1973 in the assumptions of the EfficiencyStructure (ES) model conditions welfare via X-efficiency theory. Indeed, consumer welfare can prevail only in a context of efficient management of banking costs and procyclical adjustment of bank capital.

The contribution of the Monopolistic Competition models of Salop (1979) and Rochet's natural monopoly in 1992 make it possible to propose a "discriminatory" prudential basis despite the heterogeneity of the cost management capacity. The idea is to control technically efficient or monopoly banks so as to limit barriers to entry and improve access to credit and customer welfare (VanHoose, 2017). In the regulator's view, it consists a priori of establishing a micro-prudential framework for managing banking costs. This is in addition to the macroprudential approach, whose role is to ensure the equilibrium of the financial system as a whole (Hanson et al., 2011). Following the traditional approach of micro-prudential policy, the management of banking costs, in the sense of the pioneering work of Diamond and Dybvig (1983) and Diamond (1984), makes it possible to contain the phenomena of over-thecounter shopping and/or banking panic.

The multiple crises experienced from the 1980s onwards ${ }^{3}$ led the BCBS (Basel Committee for Banking Supervision) and the BIS (Bank for International Settlements) to reconsider the issues of bank cost management on the one hand. On the other hand, they extended to the characteristics of banks deemed systemic ${ }^{4}$ and the harmonization of risk management technics. The failures of transnational banks and exchange rate crises during this period immediately supported the authorities' position to opt instead for adequate capitalization and bank capital as suitable instruments for financial stabilization and risk management (Rochet, 2008; Zeid, 2011). This led to the Basel I Accord. Under the auspices of this accord, the Cooke ratio implementation committee ${ }^{5}$ expects an inverse relationship between bank capital and bank risk. Indeed, the choice of core capital, or capital as an important variant of prudential policy, is explained by the latter's ability to internalize risks (Hanson et al., 2011). At the expense of allowing banks to benefit from the services of lenders of last resort, which are sources of moral hazard, it is considered more appropriate to force banks to bear a large part of the costs of bank risks. Either by increasing the minimum capital requirements or by providing an adequate level of capital for a given 6 level of risk. Under the first Basel Accord, the debate centered on the implications of purely cyclical bank capital adjustments on economic activity and the management of relative risks. The current dynamic, as defined by the BIS (2018), focuses on quantitative and qualitative capitalization as a guarantee of financial stability.

For several conceptions, restrictive monetary policy was indexed as the source of the financial crisis in Japan from the 1980s onwards (Bernanke and Gertler, 1995). The adoption of restrictive policy deteriorated the price of bank assets, affecting banks' profitability and their capital (and equity). Subsequent theoretical developments (Regulation Q in the United States) forced banks to adjust asset prices (interest rates) so as to promote healthy competition between capitalized and less capitalized banks. This was in order to establish intrinsic and perverse financial stability in the financial system. In the same conception by Bernanke and Gertler, the short- or long-term implications depend on the type of asset (random interest rates), the element or the targeted objective of monetary policy. Based on several studies (Bernanke and Gertler 1995; Miyao 2002), it is clear that a restrictive monetary policy has transitory effects on interest rates that negatively alter output through the inflationary process and regulatory capital adjustments. Conversely, an expansionary monetary policy will have adverse effects through the demand shock, given the increase in the money supply. In the presence of a financial stability policy adjustment, regulatory capital in any case becomes cyclical (pro- or countercyclical) (Rajan and Parulkar, 2008). Elbourne and

\footnotetext{
3 To cite just a few of the crises: the 1982 debt crisis; the problems encountered in the floating rate note market in 1986. The October crash (in 1987)

${ }^{4}$ Banks with significant market shares. Indeed, it is essential to consider for this circumstance the 3 or 5 most influential banks. ${ }^{5}$ The Cooke ratio adopted by the G10 member countries requires banks to hold risk-weighted capital equal to or greater than $8 \%$.

${ }^{6}$ The first agreements (Cooke ratio) only considered credit risks, i.e. those related to customers. Future crises in the financial systems have forced other types of risk to be taken in compliance with prudential standards (McDonough ratio of Basel II). In addition to credit, operational and market risks.
} 
Haan (2009) conclude that the contradictory effects are intrinsic to economies in the post- and pre-crisis periods. According to Facchini (2010), his work based on contemporary Austrian cycle theory, rather raises an institutional problem with regard to the effectiveness of monetary policy in ensuring financial stability in conjunction with the prudential regulator. Reference to the crisis in 2007. The latter believes that it is not enough to focus on the temporal effectiveness of monetary policy and the central banker's standards, but rather on the behavior of the proponents of that policy, namely the institutions.

The financial stability objective thus generally takes into account the implementation of monetary policy and the different channels. In this sense, these extensions have led to the proposal for a policy mix between monetary and fiscal policy. Economists generally agree on the significant short-term effects of monetary policy on the economy and/or financial stability. Indeed, the monetary cycle (adjustment of key interest rates) impinges on the supply of credit and economic output (Bernanke and Blinder, 1992) via the cost of capital. By extension, from the point of view of the credit channel, an expansionary or restrictive monetary policy may lead to the financing of the economy in the

same direction. Regulatory policy developments before and after the period of great moderation were focused on the determinants of systemic phenomena (financial instability). (Yellen, 2011). The variants indexed as potential causes of crises or financial instability were related to high accumulations of short-term banking risks, the maturity of business and/or credit cycles, and significant interconnectedness of banks.

\subsection{EMPIRICAL REVIEW}

For emerging economies, the recapitalization of capital in terms of equity has reduced the risks to which banks are exposed. An increase of at least $10 \%$ in capital requirements resulted from the adoption of the Cooke ratio (Pujal, 2003; Barajas, 2004) from 1988 onwards. Early in the 1990s, Australian banks were able to absorb the substantial losses that nearly led them to an unprecedented systemic crisis. This led to an increase in their capitalization ratio to over 9\% (Terry, 2009). However, this is a contradictory result for less developed economies. Indeed, the results obtained by Mitchell (1998) using triple least squares (3sls) estimators for Eastern Caribbean countries from 1995 onwards, conclude that there are mixed and unverified effects on the ability of banks to reduce risk through the procyclicality of capital requirements. This is explained by the low level of financial development. In the G10 countries, on the other hand, procyclical default-based capital adjustments may explain the deterioration in bank revenues (profits) providing banks with intrinsic financial stability (Nachane and Ghosh, 2001). For good reason, low diversification would explain this state of affairs (Ouédraogo, 2014). Zeid (2011) similarly finds, based on triple least squares (3sls) later, comparing the levels of capitalization and capital adequacy of banks, that an increase in bank capital (procyclicality) can expose banks to moral hazard (Das, 2002). Less capitalized banks are less riskaverse, unlike their peers.

The subsequent news on the development of idiosyncratic regulatory standards has led to a revaluation of capital or equity capital and consideration of new types of risk. Indeed, at the height of the new Basel Accord (Basel II), the issues of procyclicality of capital and counter-cyclical capital were the new prerogatives of economists and researchers. Several previous works have demonstrated the positive link between banking risks and this without ignoring profitability. On this basis, banks are forced to arbitrate between increasing their capital or reducing the risks they face (and vice versa) in order to ensure financial stability. However, there are also questions about the signal provided by the cushion or procyclical capital in a recession or boom or expansion.

According to Berenger and Teiletche (2003), the cyclicality of the capital requirements face of risks can hinder the financial stability of individual banks and affect the financing cycle of economies (Repullo et al. 2010; Ouédraogo 2014). Unlike Bharath and Shumway (2008), it appears that the explanations for the perverse effects of risk management and financial stability standards find their meaning in the methodological approaches imposed by regulatory authorities. Assorted conclusions after testing the Merton Distance Default Model. Indeed, some institutions under the Merton Distance to Default Model (DD) saw an upward revaluation of their capital ranging from $40 \%$ and $50 \%$ in the United States from 1982-2003, and especially during periods of recession (Rabell et al., 2005).

In reference to the studies of Goodhart et al (2004) on banks in Mexico, internal or probabilistic rating methods have an impact on economic activity, since banks take them into account in order to respond to requests for credit. In periods of growth explained by high returns under the internal method, banks adjust their required capital slightly, while they raise it in times of recession in order to protect themselves from the risks and rewards of 
recession or financial instability. According to Rabell et al. (2005), banks may have to respond favorably without hedging against credit risks when they are over liquid in any economic environment. This conclusion may certainly prevail depending on whether the economies are developed or developing. Barajas et al (2004), considering Latin American countries (Bolivia and Mexico), states that the procyclicality of risk coverage capital led to a contraction in credit supply of at least 16\% between 1990-1992 despite the rise in bank yields. However, he concludes that the weight of risk in assets has decreased in order to boost the supply of loanable funds through relative capital cyclicality.

Banking activity in the sense of the management of banks' portfolios and their financial situations can thus influence the procyclicality of bank capital. Indeed, for Illing and Paulin (2005), analysis conducted over 19 years in Canada concluded that banks with good financial health (A-rating) are the most likely to adjust their capital procyclically with respect to the business cycle. In addition, risky (B-rated) banks marginally improve their regulatory or risk-coverage capital in a procyclical manner, under the control of economic or business cycle conditions. In the view of Majnoni (2005), the internal capital approach becomes more procyclical and more downwardly affected than under the standard ponderation, favored in the first agreement.

It is not possible for financial risk alone to influence the adjustment of capital in such a way as to make it cyclical. However, capital itself in its regulatory constitution can be a cyclical variable and alternate economic activity. In this sense, Chandrasekhar (2008) concludes that the only proportion of bank capital (Tier 1) adjusted for risk is less efficient for Indian banks. Indeed, it starts from a distinction between regulatory capital (Tier 1) and economic capital (Tier 2) as a function of bank profit. Economic capital contains vital information about the financial stability of the financial system and a signal to investment. (Nhamias, 2013). A negative shock on this capital may justify a contraction in the supply of loanable funds and investments. (Reza, 2011) significantly affecting economic and/or financial stability. In the same consideration of Indian banks, the capital of domestic para-public, private banks had significantly increased from 1997 onwards, unlike that of foreign banks subject to internal weighting methods (ArifPasha and Kswamy, 2012). In Spain, on the other hand, capital is generally procyclical depending on the probability of default or the possibility of the bank in question going bankrupt. Thus, analyzing under the weight of discussions on alternatives to the procyclicality of Spanish banks' capital between 1987 and 2008, Repullo et al (2010) conclude that there is a positive correlation between banks' default probabilities (as opposed to exposure at default) and capitalization. For the latter, Spanish banks (large subsidiaries and/or corporate) due to their systemic characteristics increase their capital in the event of default in a significant way. This result is traditionally conceivable given the objective of prudential names to further regulate the behavior of banks whose default may cause panic in the financial system in general. (Mishkin, 2010).

\section{FINANCIAL STABILITY AND PROCYCLICALITY OF BANK CAPITAL BASE: THE STYLIZED FACTS}

As a result, adjustments to the regulatory capital of banks in CEMAC were procyclically revalued in response to adverse financial trends just after the subprime crisis of 2007 to 10 billion in 2009. Moreover, the sensitivities of macroeconomic variables in the sense of the Schumpeterian conception of financial involvement have not been conclusive, at least not positive. The falls in commodity prices (cocoa, cotton and oil) have impinged on cyclical adjustments (pro- and countercyclical) in the economic context of CEMAC countries. The figures in Appendix 4 show that during the 2007 crisis, bank capital was procyclical in relation to default risks (Figure 2). CEMAC banks took potential positions to ensure the stability of the financial system in the face of the crisis. For Djimoudjiel (2018) from 2009 onwards, considering Chadian banks and the level of risks they face, the procyclicality of their capital has rather amplified the risky behavior of customers. This has also hampered the financial development process. The case of other countries in the sub region does not, however, remain contrasted or mixed.

It must be acknowledged that in terms of exogenous shocks during the subprime crisis, the financial system of CEMAC countries was less exposed than that of developed economies. For the simple case of countries such as those of the WAEMU, capitalization was increased in order to cover risks against arbitrage in the financing of economies (Ouédraogo, 2014). The figure above shows a strong procyclical increase in the capital base in the first quarter of 2008 for all countries. Chad and the Central African Republic are the two countries whose total share of bank capital in CEMAC remains low throughout the period (2010Q1 to 2017Q1). Congo, Gabon, and Cameroon are the group of countries whose capital leaves a purely cyclical trend as of the third quarter of 2012 (Appendix 4). In the first quarter of 2012, bank capitalization declined by CFAF 3785 million to increase along the period with a strong variation in 
the first quarter of 2017 (CFAF 417857 million). Congo only recorded a capital decrease of 5251 million FCFA in early 2014, unlike Gabonese banks, which were impacted by constant capital variations. From the first quarters of 2014 to 2015, there will be significant falls of at least CFAF 5,832 million. Thus, in relation to Figure 2, the evolution of bank capital has continued with mixed trends (pro- and countercyclical) in the face of the recession and the risk of defaults in the various countries. Indeed, Chad and Equatorial Guinea had previously had modest variations in their banks' capital (despite being procyclical, they were small). In addition, in the first quarter of 2016, there was a declining change in capital in all countries and this in a significant way (Figure 1).

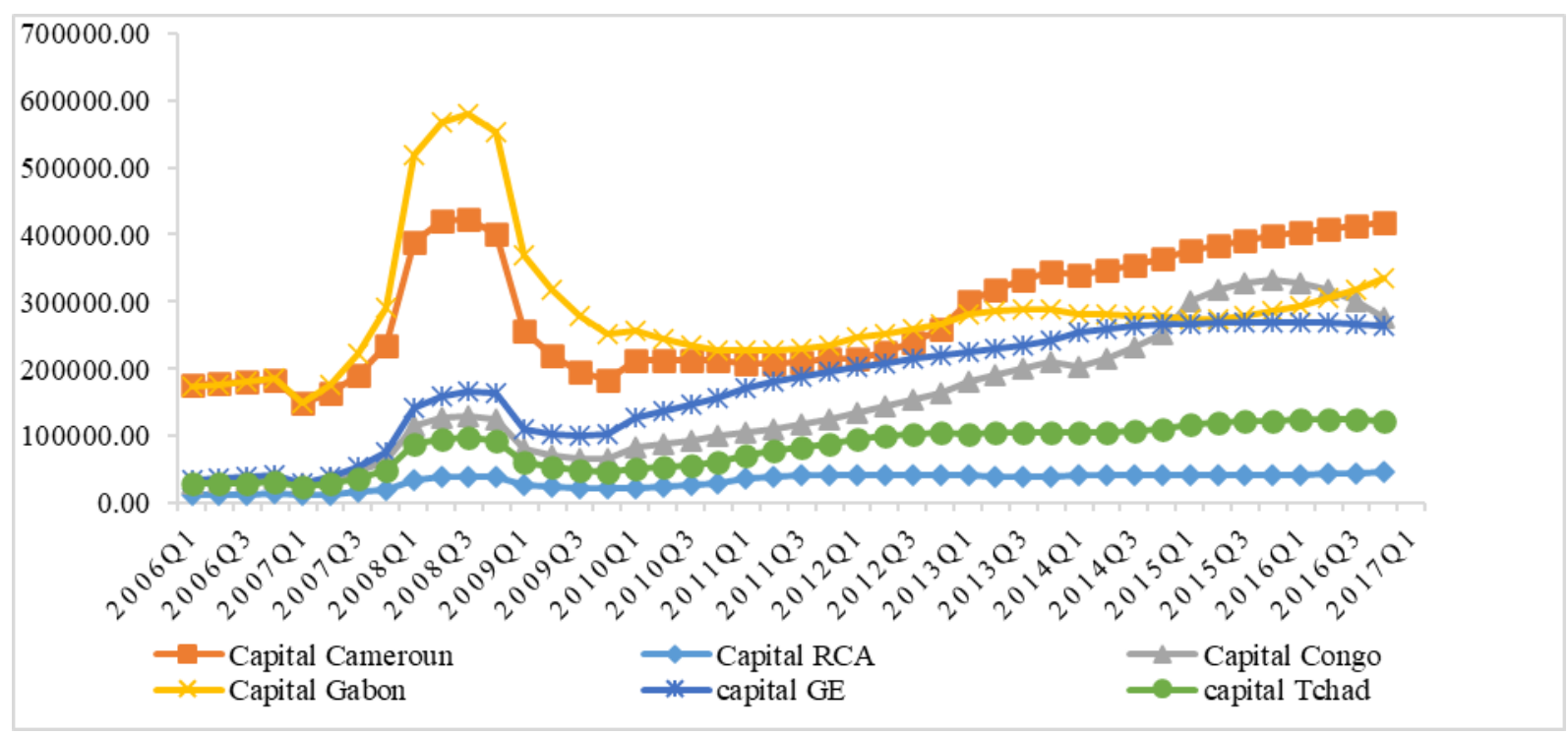

Source: Authors

Figure 1: Evolution of the capital base of banks in CEMAC

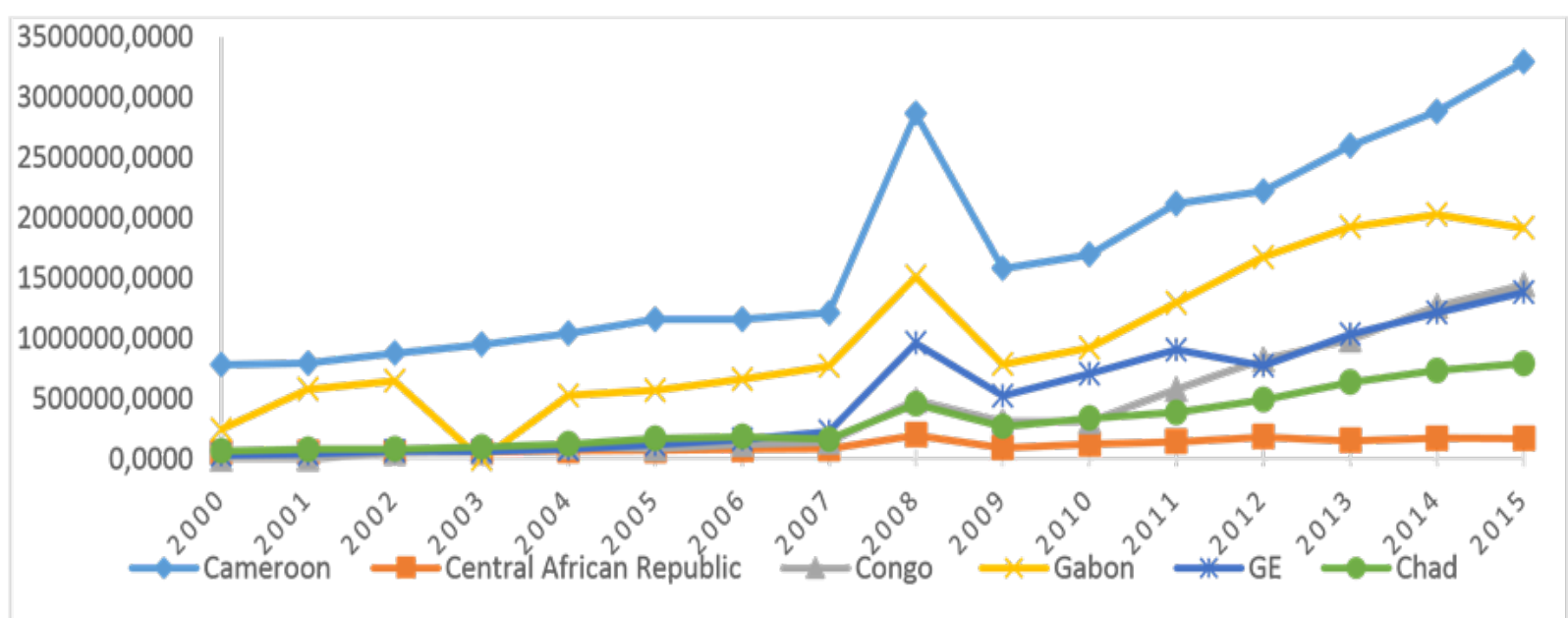

Source: Authors

Figure 2: Loss of Default in Standard Weighting

Largely dependent on oil resources, the shocks expected by CEMAC countries have had a severe impact on the economic system and economic resilience. Bank recapitalization trends following the shock simply followed the course of macroeconomic indicators in periods of recession. It would be difficult, however, to conclude from the countercyclical nature of capital (equity), a capacity to finance economies and guarantee the internal stability of the system as a whole. Guaranteeing financial stability helps to accompany price stabilization by adjusting the director interest rate (TIAO). However, the authority in charge of monetary policy has a duty to influence the money supply according to the economic trend and the banks' ability to free up idle funds. In an aggregate (aggregated) manner, Figures 1 and 3 show a joint evolution of the M2 money supply and the recapitalization process. The Appendixed figures show a more random response of the inflation rate to the TIAO for the vast majority of countries, with the 
exception of Equatorial Guinea and Chad. On the other hand, the TIAO-Inflation-Capital gaps are more observable from the first quarters of 2014 onwards. The TIAO fell from $5.25 \%$ to $2.45 \%$ succinctly because of the subprime crisis (2007) and the recent oil shocks (Bikai and Essiane, 2017).

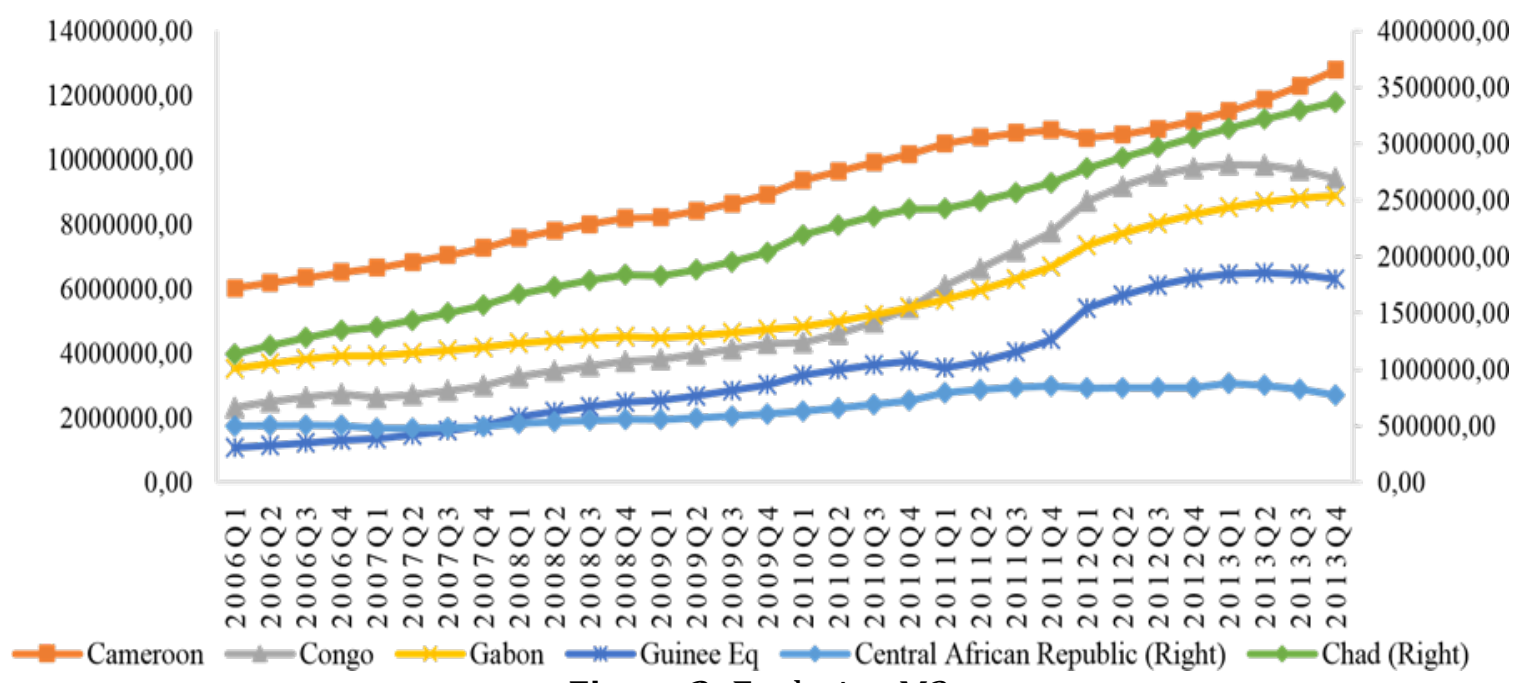

Source: Authors

Figure 3: Evolution M2

\section{METHODOLOGY AND DATA SOURCE}

\subsection{ECONOMETRIC MODEL AND ESTIMATION TECHNIQUE}

The work on the implications of bank capital cyclicality on financial and economic activity

(Ouédraogo, 2014; Djimoudjiel, 2018) has drawn heavily on the modelling of Shrieves and Dahl (1992) in simultaneous equations of the various interactions. The objective of this paper is to apprehend the procyclicality effects of required capital and the adjustment of monetary policy instruments on financial stability in the CEMAC region. The group of endogenous financial stability variables consists of loans to the sector (Cpriv) and to public enterprises (Cpub). Exogenous variables such as the key interest rate (TIA0), the money supply (M2) and the inflation rate (Infl) are the group of indicators that influence financial stability to some extent. GDP (Gross Domestic Product) and oil rents (Rep_pib) are the exogenous control variables. As for regulatory capital ( $\Delta$ CAPR), it is given by the ratio between core capital or equity capital and credit risk weighted assets. The risk weighting is done under the OECD standard approach.

The form of the vector autoregressive process (VAR) considered is as follows:

$$
y_{t}=A+\sum_{j=1}^{m} \varphi_{j} y_{t-j}+\sum_{j=1}^{m} \phi_{j} x_{t-j}+\varepsilon_{t}
$$

Assuming the unheard-of existence of unobserved heterogeneity among the individuals in the model, the model can be rewritten as follows:

$$
y_{t}=a_{0}+\sum_{j=1}^{m} \varphi_{j} y_{t-j}+\sum_{j=1}^{m} \phi_{j} x_{t-j}+\eta_{i}+\gamma_{t}+\theta_{i t}(2) \varepsilon_{t}=\eta_{i}+\gamma_{t}+\theta_{i t}(3)
$$

With:

- $a_{0}$ the vector of constants. $y_{t}$ is the vector of the time series of variables.

- $\varepsilon_{t}$ the error vector following a normal distribution of mean 0 and variance $\sum$. 
- $\eta_{i}$ are the individual effects representing the set of structural or non-temporal specificities of the endogenous variable, different from one individual to another.

- $\gamma_{t}, \theta_{i t}$ represent the temporal effects that are identical for all individuals and the component of the residue that $\varepsilon_{i t}$ integrates the individual and temporal effects at the same time.

The choice of a structural autoregressive variable model will allow for restrictions on the response of procyclical capital shocks to financial stability from the perspective of financing the economy and adjusting monetary aggregates. The Cholesky decomposition of the variance matrix will result in a triangularisation explaining the effects of one variable on another, given its position in the chain of matrices. The assumed matrix of stocks proposed by Cholesky:

$$
\Sigma=\left[\begin{array}{cccc}
z_{11} & 0 & 0 & 0 \\
z_{21} & z_{22} & 0 & 0 \\
z_{31} & z_{32} & z_{33} & 0 \\
\cdots & \cdots & \cdots & \cdots \\
z_{k 1} & z_{k 2} & z_{k 3} & z_{k n}
\end{array}\right]
$$

The specification of the structural model of the autoregressive variables to be estimated can be defined as follows:

$$
A_{0} y_{t}=\beta+\sum_{i=1}^{m} A_{i} y_{t-1}+\varepsilon_{t}
$$

$\varepsilon_{t}$ considered as structural shocks with the same characteristics of the VARs of general form. is $y_{t}$ the group of endogenous variables (cap_procyclical, cpriv, cpub, tiao, infl, Im2, Ipib, Rep_pib). A is the identity matrix allowing to identify the variable explained at the level of each equation considered.

$$
y_{t}=\frac{\beta}{A_{0}}+\frac{1}{A_{0}} \sum_{i=1}^{m} A_{i} y_{t-1}+A_{0}^{-1} \varepsilon_{t}
$$

Either from $v_{t}=A_{0}^{-1} \varepsilon_{t}$ where $v_{t} \equiv\left[v_{t}^{y_{t}}\right]=A_{0}^{-1}\left[\varepsilon^{y_{t}}\right](7)$

With the $v_{t}=y_{t}-\frac{\beta}{A_{0}}-\frac{1}{A_{0}} \sum_{i=1}^{m} A_{i} y_{t-1}(8)$ residue vector estimated using endogenous variables $y_{t}$

In the autoregressive variables model, the structural restrictions to be imposed on the matrices will be of the order of the formula of the restrictions imposed on the matrices $n=\frac{k(k-1)}{2} \cdot k$ the number 2 of endogenous variables in the model.

$\varepsilon_{t}$ : the vector of structural shocks of the endogenous variables considered in the estimation model. Thus we consider the main shocks such as $e^{\text {cap }}$ procyclical, $e^{\text {cpriv }} e^{\text {cpub }}, e^{\text {tiao }}$ as endogenous shocks. The shocks $e^{\text {infl }}$ and $e_{t}^{l m 2}$ are endogenous and exogenous nature. 
Table 1: Structural restrictions and nature of shocks

\begin{tabular}{|c|c|c|}
\hline Variable & Assumed nature of the shock & \multirow{8}{*}{ 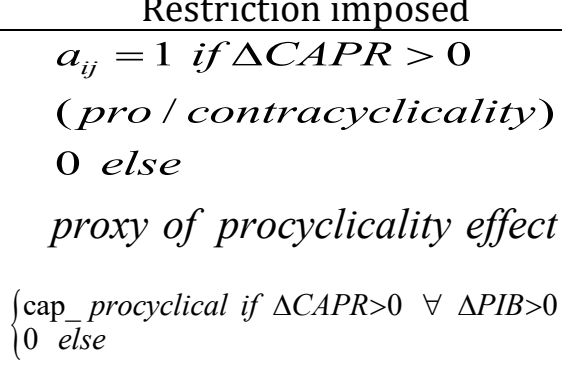 } \\
\hline CPRI & $\mathrm{N}$ & \\
\hline CPUB & $\mathrm{N}$ & \\
\hline TIAO & $\mathrm{N}$ & \\
\hline INFL & $\mathrm{N} / \mathrm{X}^{* *}$ & \\
\hline LM2 & $\mathrm{N} / \mathrm{X}$ & \\
\hline PIB & $\mathrm{N} / \mathrm{X}$ & \\
\hline Rep_pib & $\mathrm{X}$ & \\
\hline
\end{tabular}

** $\mathrm{N}$ and $\mathrm{X}$ indicate respectively the shocks assumed to be endogenous or exogenous to the model. Source: Authors

Table 1 shows the structural restrictions on the coefficients of the endogenous variables chosen in accordance with the prior objectives of the article. The restrictions imposed consider a situation in which changes in banks' regulatory capital become procyclical following a period of economic expansion (Mojon, 1996; Repullo et al., 2010) or following a rise in default losses. However, we do not rule out other transmission channels. Thus, procyclical adjustments of regulatory capital relative to risk-weighted assets are measured in terms of the joint period changes in the growth rate in each country. The impulse responses of financial stability are assessed by the logarithm of credits to economies (CPRIV and CPUB) of the money supply (M2), the TIAO and the inflationary process (INFL).

The matrix $\mathrm{Ae}=\mathrm{Bu}$ where $\mathrm{E}[\mathrm{uu}$ '] is the identity matrix with restrictions taken into account can be specified as follows:

$\left[\begin{array}{c}e_{t}^{\text {cap_procyclical }} \\ e_{t}^{c p r i v} \\ e_{t}^{c p u b} \\ e_{t}^{\text {tiao }} \\ e_{t}^{\text {inf } l} \\ e_{t}^{l m 2} \\ e_{t}^{\text {pib }} \\ e_{t}^{\operatorname{Re} p_{-} p i b}\end{array}\right]=\left[\begin{array}{cccccccc}1 & 0 & 0 & 0 & 0 & 0 & 0 & b_{18} \\ b_{21} & 1 & 0 & 0 & 0 & b_{26} & 0 & 0 \\ b_{31} & 0 & 1 & 0 & 0 & b_{36} & 0 & 0 \\ b_{41} & 0 & 0 & 1 & 0 & b_{46} & 0 & 0 \\ 0 & 0 & 0 & 0 & 1 & b_{56} & 0 & 0 \\ 0 & 0 & 0 & 0 & 0 & 1 & 0 & 0 \\ 0 & 0 & 0 & b_{74} & 0 & 0 & 1 & 0 \\ b_{81} & 0 & 0 & 0 & 0 & 0 & 0 & 1\end{array}\right]\left[\begin{array}{c}u_{t}^{c a p}+\text { procyclical } \\ u_{t}^{\text {cpriv }} \\ u_{t}^{\text {cpub }} \\ u_{t}^{\text {tiao }} \\ u_{t}^{\text {inf } l} \\ u_{t}^{l m 2} \\ u_{t}^{\text {pib }} \\ u_{t}^{\operatorname{Re} p_{-} p i b}\end{array}\right]$

In addition, the implications for the real sector of the economy will be captured via the logarithm of GDP. In the vast majority of oil-producing countries, taking into account oil rents (Rep_pib) will make it possible to apprehend the impulses of the adjustment behavior of capital, taking into account the current recession. This variable will be expressed as a percentage of GDP.

The effects of procyclicality shocks will be estimated using the structural factorization method, which consists of making certain values in the A matrix non-zero. However, this technique exposes the model to problems of underidentification that can bias (make it difficult) the estimated results of the reduced-form model.

\subsection{DATA SOURCE}

The data used in this article come from the BEAC and the COBAC for the variable capitalization, profitability, TIAO, foreign exchange reserves and the inflation rate. In addition, the GDP variable is derived from the IMF database. In order to broaden the horizons of the study, some data available at annual frequency have been quarterlyized. In order to incorporate the dynamics of bank capital adjustment following the 2007 crisis and the recapitalization norm in 2009, we have chosen the data range from 2006 to 2017. 
Does the Procyclicality of Capital Requirements Affect Financial Stability in Cemac?

\subsection{DESCRIPTIVE STATISTICS AND PRELIMINARY TESTS}

\subsubsection{DESCRIPTIVE STATISTICS}

Table 2: statistics

\begin{tabular}{|c|c|c|c|c|c|c|c|c|}
\hline & PRO-CYCLICAL_CAP & CPRIV & CPUB & TIAO & INFL & LM2 & LPIB & REP_GDP \\
\hline Average & $1.53 E-05$ & 5.724 & 4.325 & 4.445 & 3.717 & 15.314 & 8.887 & 30.24 \\
\hline Maxi & 0.014 & 6.355 & 5.413 & 5.505 & 15.246 & 16.363 & 9.619 & 58.51 \\
\hline Min & -0.048 & 4.350 & 1.751 & 3.542 & -7.417 & 13.948 & 8.156 & 2.803 \\
\hline Obser. & 150 & 150 & 150 & 150 & 150 & 150 & 150 & 150 \\
\hline
\end{tabular}

Source: Authors

The above table shows that the procyclical variation of capital in relation to the total balance sheet or weighted assets of banks in recession or economic expansion over the study period reaches a maximum of CFAF 0.014 billion. The share of bank credit granted to private and public enterprises averaged CFAF 5.72 and 4.32 billion respectively. Despite the context of over liquidity recognized to the countries of the sub-region, the level of the consumer price index reached 15\% justified by the economic activity in the Central African Republic and Chad from 2012 onwards

\subsubsection{STATIONARITY TESTS AND DETERMINATION OF THE NUMBER OF DELAYS}

The stationarity test is used to correctly estimate the specified VARS. Because of the use of panel data, the tests of Levin-Lin-Chu (2002) and Im-Pesaran-Shin (2003) will be retained because they incorporate stationarity models with or without constancy, with constancy and trend (Ouédraogo, 2014).

The results above show that the variables are for the most part stationary in the first difference, except in the case of procyclical changes in bank capital. However, in the sense of Andrews and Zivot, there may be phases of disruption that could cause some of the level variables to become stationary. The search for the number of lags reveals a lag of around 2 according to Schwartz's and Hannan-Quinn's information criteria (see Appendix 1).

Table 3: Stationarity test results

\begin{tabular}{|c|c|c|c|c|c|}
\hline Variables & LLC & Level ADF & IPS & ADF in difference & stationarity \\
\hline Cap_Procyclical & -3.55 & 38.8937 & -3.905 & & $\mathrm{I}(0)$ \\
\hline CPRIV & 10.1194 & & -3.23740 & 33.9822 & $\mathrm{I}(1)$ \\
\hline CPUB & 0.76816 & & -3.43055 & 34.8613 & $\mathrm{I}(1)$ \\
\hline TIAO & 0.8287 & & -2.50971 & 23.7216 & $\mathrm{I}(1)$ \\
\hline INFL & -2.324 & & -4.65549 & 46.6489 & $\mathrm{I}(1)$ \\
\hline LM2 & 1.17839 & & -1.77283 & 19.7953 & $\mathrm{I}(1)$ \\
\hline LPIB & 0.13407 & & -3.48118 & 33.2164 & $\mathrm{I}(1)$ \\
\hline REP_GDP & 1.26724 & & -2.98749 & 25.3961 & $\mathrm{I}(1)$ \\
\hline
\end{tabular}

Source: Authors

\section{RESULTS AND INTERPRETATIONS}

Structural autoregressive analyses consider a priori the variables taken into account as endogenous to the base (unless constraints or restrictions are imposed at the base). The contribution of the structural shocks exercise made it possible to highlight the results of the short-term effects thanks to the constraints imposed and based on the literature. However, in extension, the imposition of long-term restrictions made it possible to extend the analysis.

\subsection{SHORT-TERM EFFECT}

The following table shows the results of the short-term shocks of procyclical capital requirements under riskconstrained conditions. The coefficients of the restrictions imposed are given by $\mathrm{C}(3), \mathrm{C}(6), \mathrm{C}(9)$, and $\mathrm{C}(17)$. The 
other coefficients (C (4), C (7), C (10), C (12), C (15)) are those of the restrictions in order to identify the likely interactions of the effects of shocks in the monetary policy response in a context of prudential regulation based on regulatory capital.

In general, the results show that the imposition of the restrictions that procyclicality of capital required affects financial stability remains more or less valid. Indeed, on the one hand, it appears that in the short term the procyclical shock of risk-adjusted bank capital leads to a contraction in the supply of credit to the economy and more particularly to the private sectors of CEMAC countries. A 1\% increase in regulatory capital leads to a significant contraction of credit to at least $3.07 \%$. Result of the significant shock at the $1 \%$ threshold. These results are in line with the conclusions of Illing and Paulin (2005) for which the procyclicality of capital adjusts to economic trends or business cycles. Similarly, in relation to the work of de Berenger and Teiletche (2003) and Repullo et al (2010), risk hedging approaches are in some ways a bottleneck in the supply of credit and business cycle financing. Customers considered too risky under, for example, the probabilistic determination of defaults and credit losses approach. While the credit granted to public enterprises is not influenced by the procyclical adjustment of banks' capital, the joint interaction with the TIAO policy rate improves financial stability in the CEMAC zone. Indeed, it appears that a positive shock of $1 \%$ of the key rate (expansionary monetary policy) has positive effects at the threshold of $1 \%$ of significance, on economic activity (GDP) at $0.26 \%$. In conjunction with the work of Bernanke and Gertler (1995) and Caporale and Mckiernan (1999), monetary policy shocks can have intrinsic and redundant effects on real activity in the short term. There are positive and significant effects on short-term economic activity at the 1 per cent threshold for the restriction of policy rate shocks. Despite the low coefficient of the effects of monetary policy adjustment, the behavior of banks to adjust their capital in a regulatory environment has little influence on financial stability.

Table 4: Results of short-term structural shocks

\begin{tabular}{|c|c|c|c|}
\hline \multicolumn{4}{|c|}{$\begin{array}{l}\text { Structural VAR Estimates } \\
\text { Sample (adjusted) : 2006Q4 2013Q4 } \\
\text { Included observations : } 130 \text { after adjustments } \\
\text { Estimation method: method of scoring (analytic derivatives) }\end{array}$} \\
\hline \multicolumn{3}{|c|}{ Coefficient } & \\
\hline $\mathrm{C}(3)$ & $-3,079137 * * *$ & & 0,0013 \\
\hline $\mathrm{C}(4)$ & $1,235714^{* * *}$ & & 0,0000 \\
\hline $\mathrm{C}(6)$ & $-2,206417$ & & 0,1589 \\
\hline $\mathrm{C}(7)$ & $1,972679 * * *$ & & 0,0000 \\
\hline$C(9)$ & $-3,269285^{* * *}$ & & 0,0093 \\
\hline $\mathrm{C}(10)$ & $0,767848^{* * *}$ & & 0,0026 \\
\hline $\mathrm{C}(12)$ & $19,05624^{* * *}$ & & 0,0007 \\
\hline $\mathrm{C}(15)$ & $0,269668^{* * *}$ & & 0,0000 \\
\hline $\mathrm{C}(17)$ & $-107,7416^{* * *}$ & & 0,0014 \\
\hline Log likelihood & 923,0440 & & \\
\hline \multicolumn{2}{|c|}{ LR test for over-identification: } & Probability & 0,0000 \\
\hline
\end{tabular}

$\mathrm{C}($.$) express the coefficients of the restrictions of structural shocks (see Appendix 2$ for identification of restrictions). ${ }^{* *},{ }^{* *}$ and $*$ express the significativities at the threshold of $1 \%, 5 \%$ and $10 \%$.

Source: Authors

Similarly, the money supply response (LM2) of this policy leaves positive effects on financial stability. In the sense of Fernández et al (2012), the increased regulatory constraint in the objective of financial stability makes it possible to revive an economy. It thus remains undeniable and consistent that a strong increase in the money supply explains the procyclical variables (when setting the effects or prudential constraints of financial stability).

In terms of country effects (see Appendix 4), procyclical regulatory capital adjustments contrast in their effects on financial stability in Cameroon, Equatorial Guinea and Chad, but marginally in the case of Congo and Gabon. According to Mitchell (1998), as presented for the case of Caribbean banks, low financial development is at the root of this fact. In the first five (5) quarters, a procyclical shock to the said capital led to an improvement in the level of 
credit to the private and public sectors of at least $0.5 \%$ in Cameroon. In Equatorial Guinea, on the other hand, the effects are slightly negative $(0.2 \%)$. Chad and Gabon, on the other hand, suggest more uncertain responses. The effects on financial stability remain more controversial. In fact, it appears that when banks adjust their required capital in a procyclically, in the short term there is a $0.17 \%$ contraction of credit to public enterprises (sectors). The response of the inflationary process remains positive and is explained by the positive effect of $0.02 \%$ on credits to the private sectors. While the response of the price level to the shocks is positive, an increase in regulatory capital intrinsically mitigates inflationary trends on average in the CEMAC countries (accentuated effects in the Central African Republic and Chad).

\subsection{LONG-TERM EFFECTS}

The long-term restrictions imposed relate mainly to the effects of procyclical capital requirements adjustments on credit to the corporate and public sectors. However, relative to the approach of Bernanke and Blinder (1992), restrictions on the long-run shocks of monetary policy instruments to the procyclicality of bank capital have been imposed.

In contrast to short-term shocks, the long-term effects of procyclical capital adjustment on financial stability variables (credits granted to the public and private sectors) become significant at the $10 \%$ and $5 \%$ thresholds respectively. Indeed, the sustained shock of procyclicality of capital with a view to ensuring the resilience of the banking sector in the CEMAC improves the capacity of banks to meet the demand for credit. Intrinsically, the effects are greater on the price level (inflation) via the same credit channel. While credit access facilities improved in the long term by $0.022 \%$ and $0.030 \%$ respectively for the private and public sectors following the procyclical shock (by $1 \%$ ), the fallout in terms of inflation was at least 3\%. However, it appears that an adjustment of the key rate (TIA0) in a restrictive dynamic reduces marginally ( 0.0006 point) the regulatory bank capital. This decline is explained either by an increase in credit risks or a slowdown in activities in conjunction with the TIAO policy and the response of the money supply.

Table 5: Results of long-term structural shocks

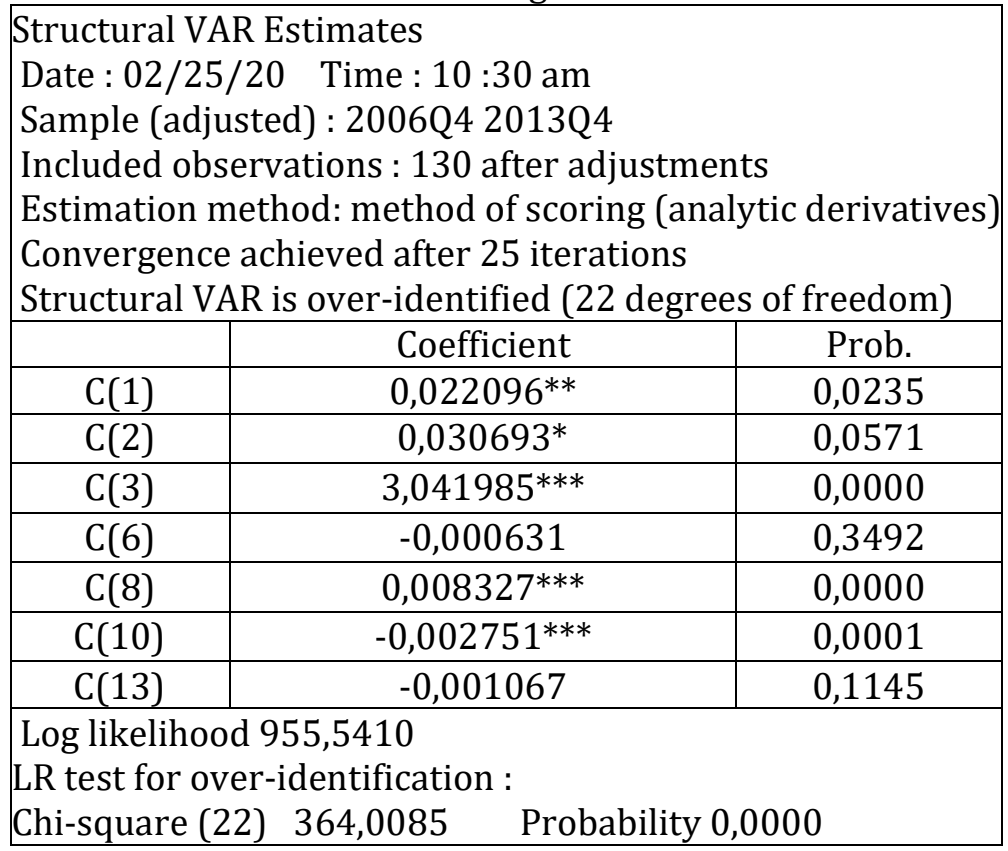

$\mathrm{C}($.$) express the coefficients of the restrictions of structural shocks (see Appendix 3$ for identification of restrictions). ${ }^{* *},{ }^{* *}$ and $*$ express the significativities at the threshold of $1 \%, 5 \%$ and $10 \%$.

Source: Authors

As for the shocks due to the fall in oil prices, apart from the contraction in GDP that it causes (Bikai and Essiane, 2017), the effects extend to the banks' ability to cover risks with capital. In the same vein as Berenger and Teiletche (2003) and Barajas et al. (2004), the passages of the various Basel agreements have led to a reciprocal dependence 
between the adjustment of regulatory capital and the phases of economic expansion and recession, as opposed to credit risks.

\section{CONCLUSION}

This article aims to show in which cases the procyclical variation of the capital requirement according to economic constraints and risks can affect financial stability in CEMAC countries. In other words, it is hypothesized that the procyclical adjustment of regulatory capital conditions the improvement of the financial situation in the CEMAC zone. By using structural restrictions on procyclical changes in regulatory capital, using data from the first quarter of 2006 to the fourth quarter of 2017, it appears that shocks to bank capital required and its procyclicality have a positive but small short-term impact on financial stability in the CEMAC region. Taking into account the variables of financial instability, the trade-off made by banks in a regulatory context seems more constraining for private sector financing in the short term. This significant effect is jointly supported by an expansionary monetary policy. Apart from the negative impulses on the key rate, the inflationary response remains non-negligible (more than $1.5 \%$ ). Indeed, in the procyclical adjustment dynamism of regulatory capital, the low implications on financial stability (money supply, GDP) justify the low level of financial development in CEMAC. In the long run, the effects of the procyclicality of regulatory capital become more significant but less constraining on financial stability. In the context of developed economies, the long-term dynamics are for the context of developed economies in the context of regulation are fixed on the management of credit risks, constraint of financing (access to loanable funds). Moreover, financial stability remains more influenced by adjustments in long-term monetary policy instruments.

\section{APPENDICES}

Appendix 1: determining the number of delays

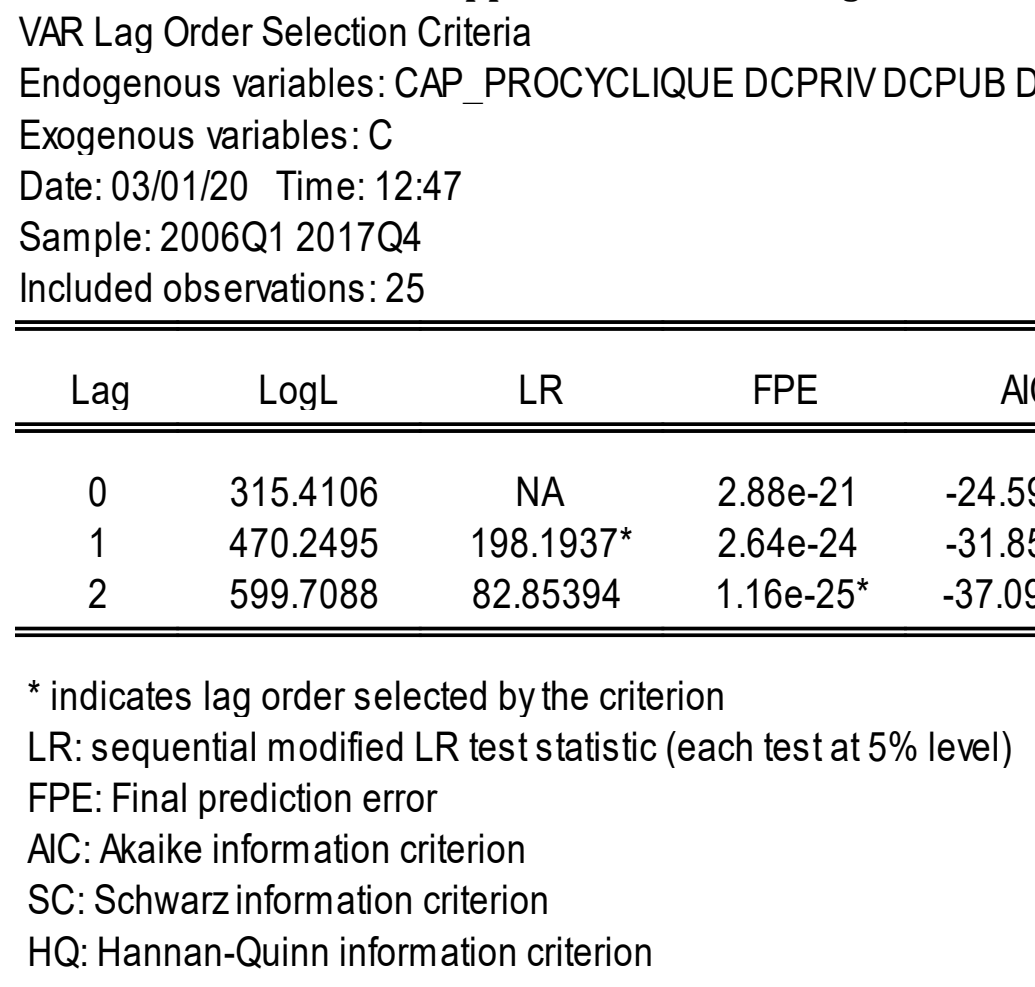


Does the Procyclicality of Capital Requirements Affect Financial Stability in Cemac?

\begin{tabular}{|c|c|c|c|c|}
\hline \multicolumn{5}{|c|}{ Appendix 2: Results of Short-Term Shocks } \\
\hline \multicolumn{5}{|c|}{$\begin{array}{l}\text { Structural VAR Estimates } \\
\text { Date: } 02 / 25 / 20 \text { Time: } 10: 30 \\
\text { Sample (adjusted): } 2006 \mathrm{Q} 42013 \mathrm{Q} 4 \\
\text { Included observations: } 130 \text { after adjustments } \\
\text { Estimation method: method of scoring (analytic derivatives) } \\
\text { Convergence achieved after } 12 \text { iterations } \\
\text { Structural VAR is over-identified (19 degrees of freedom) }\end{array}$} \\
\hline \multicolumn{5}{|c|}{ 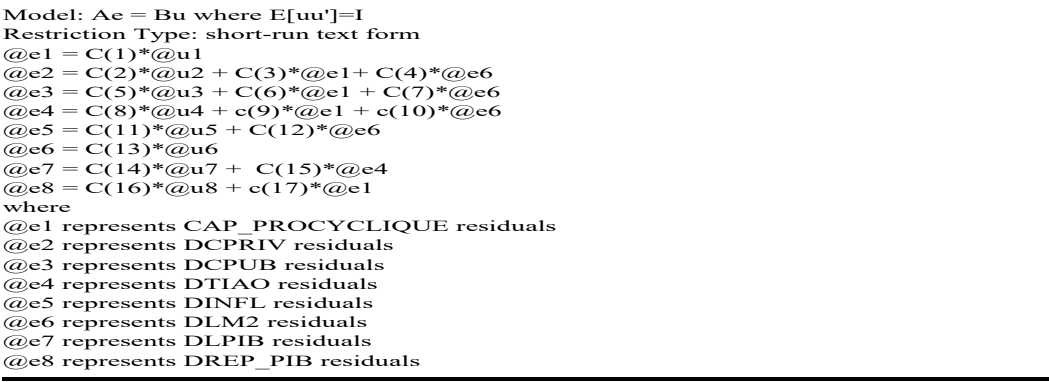 } \\
\hline & Coefficient & Std. Error & z-Statistic & Prob. \\
\hline$C(3)$ & -3.079137 & 0.957152 & -3.216980 & 0.0013 \\
\hline$C(4)$ & 1.235714 & 0.194288 & 6.360227 & 0.0000 \\
\hline$c(6)$ & -2.206417 & 1.566140 & -1.408825 & 0.1589 \\
\hline$C(7)$ & 1.972679 & 0.317904 & 6.205276 & 0.0000 \\
\hline$C(9)$ & -3.269285 & 1.256624 & -2.601640 & 0.0093 \\
\hline$C(10)$ & 0.767848 & 0.255076 & 3.010266 & 0.0026 \\
\hline$C(12)$ & 19.05624 & 5.641983 & 3.377579 & 0.0007 \\
\hline$C(15)$ & 0.269668 & 0.034761 & 7.757684 & 0.0000 \\
\hline$C(17)$ & -107.7416 & 33.76735 & -3.190704 & 0.0014 \\
\hline$c(1)$ & 0.005595 & 0.000347 & 16.12452 & 0.0000 \\
\hline$C(2)$ & 0.061059 & 0.003787 & 16.12452 & 0.0000 \\
\hline C(5) & 0.099908 & 0.006196 & 16.12452 & 0.0000 \\
\hline$C(8)$ & 0.080163 & 0.004972 & 16.12452 & 0.0000 \\
\hline$C\left(\begin{array}{lll}1 & 1\end{array}\right)$ & 1.773119 & 0.109964 & 16.12452 & 0.0000 \\
\hline$C(13)$ & 0.027563 & 0.001709 & 16.12452 & 0.0000 \\
\hline$C(14)$ & 0.033651 & 0.002087 & 16.12452 & 0.0000 \\
\hline$C(16)$ & 2.154109 & 0.133592 & 16.12452 & 0.0000 \\
\hline \multirow{2}{*}{\multicolumn{5}{|c|}{$\begin{array}{l}\text { Log likelihood } \\
\text { LR test for over }\end{array}$}} \\
\hline \multirow{2}{*}{\multicolumn{5}{|c|}{$\begin{array}{l}\text { LR test for over } \\
\text { Chi-square(19) }\end{array}$}} \\
\hline & 429.0024 & & & 0.0000 \\
\hline
\end{tabular}

- $\quad$ Single VAR (1)

cap_procyclical dcpriv dcpub dtiao infl dlm2 dlpib drep_pib

- Constrained SVAR with structural shocks (short-term effects)

Source: Authors

Appendix 3: Result of long-term shocks

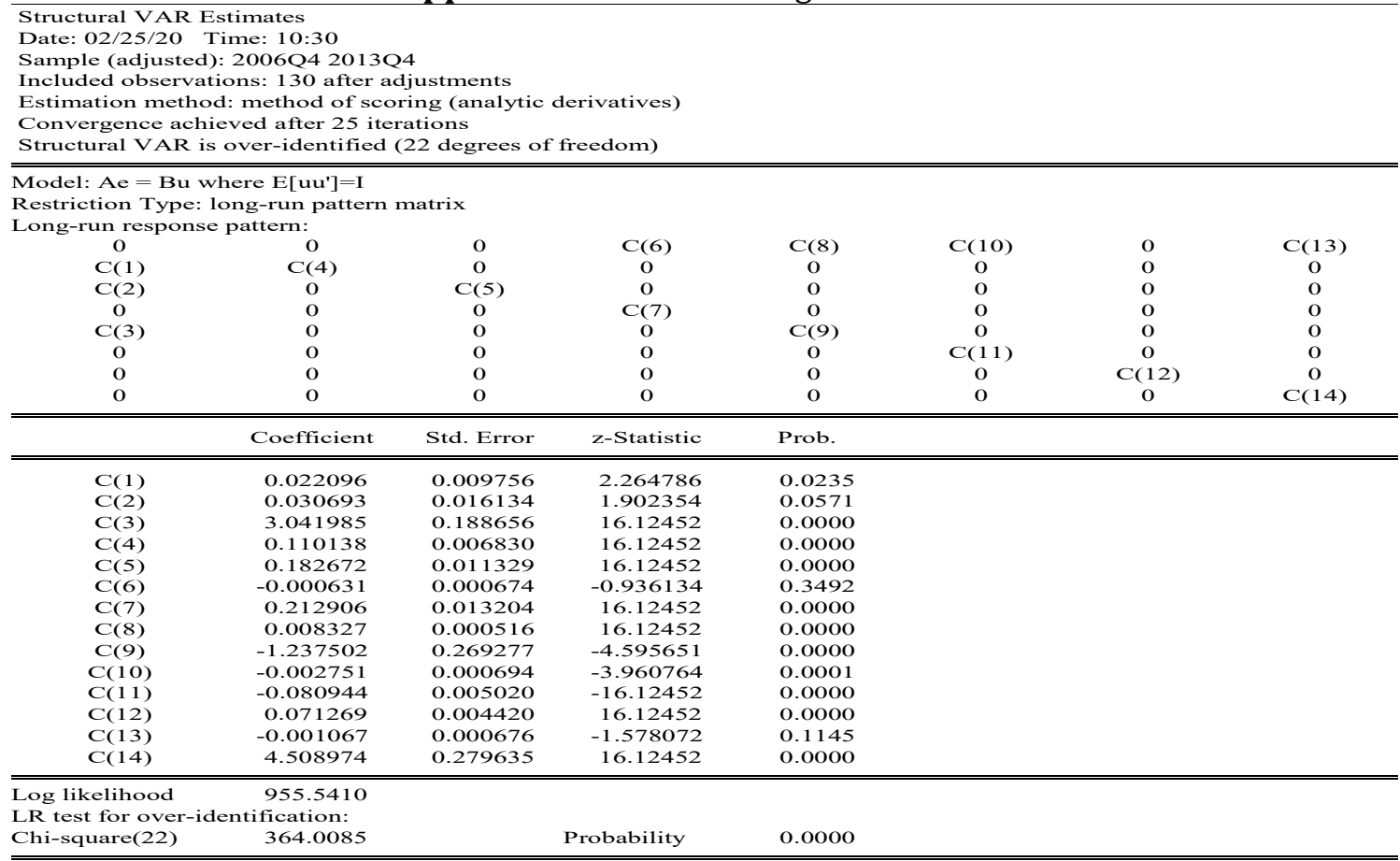

Source: Authors

International Journal of Research -GRANTHAALAYAH 
Djimoudjiel Djekonbé, Ningaye Paul, and Nafé Daba

Appendix 4: Financial stability impulse responses

Response of DCPRIV to Shock1

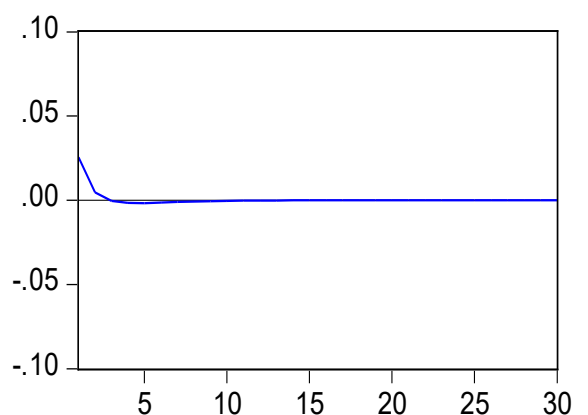

Response of DCPUB to Shock1

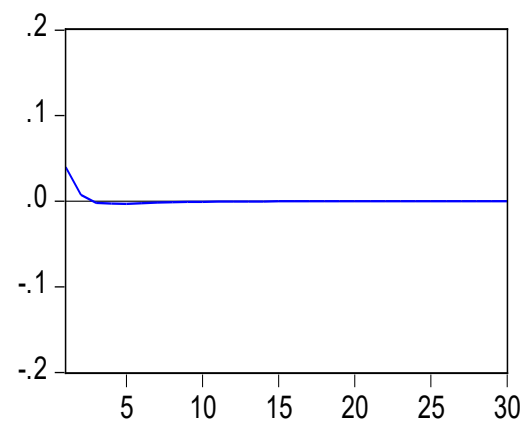

Response of DINFL to Shock1

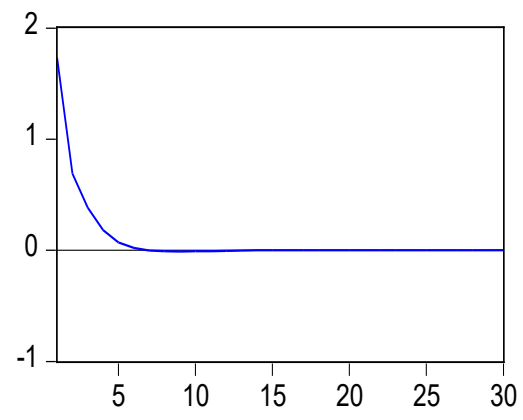
Response of CAP_PROCYCLIQUE to Shock4
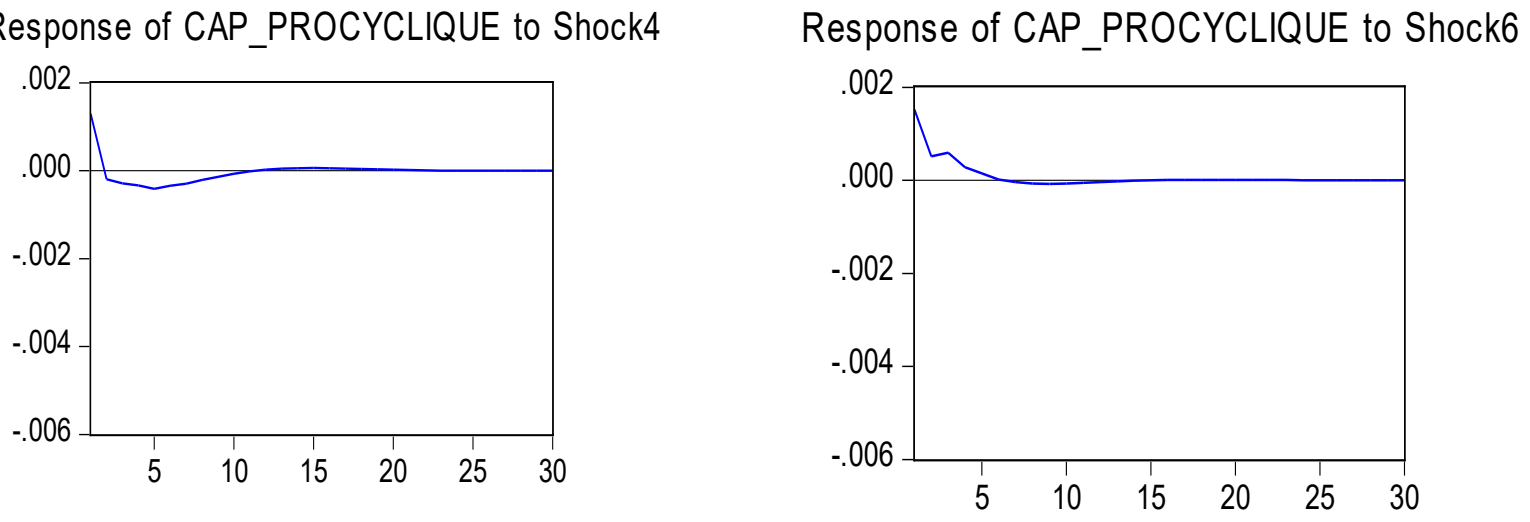

Appendix 5: Idiosyncratic shocks in CEMAC

\section{Cameroun}
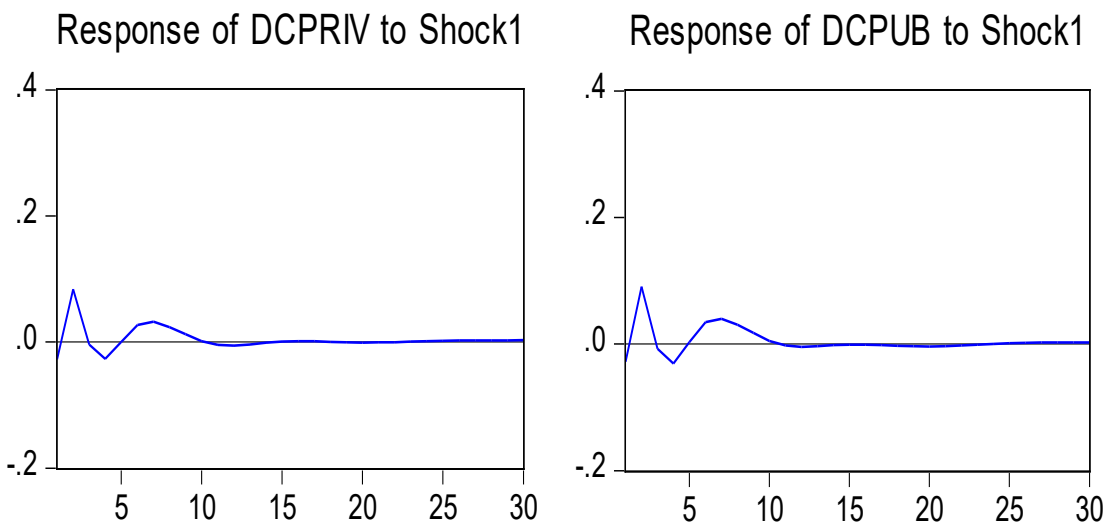

Response of DINFL to Shock1

Response of CAP_PROCYCLIQUE to Shock4

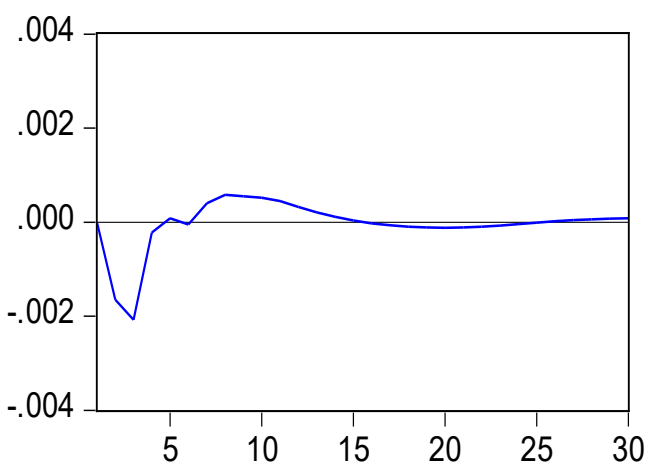

Response of CAP_PROCYCLIQUE to Shock6
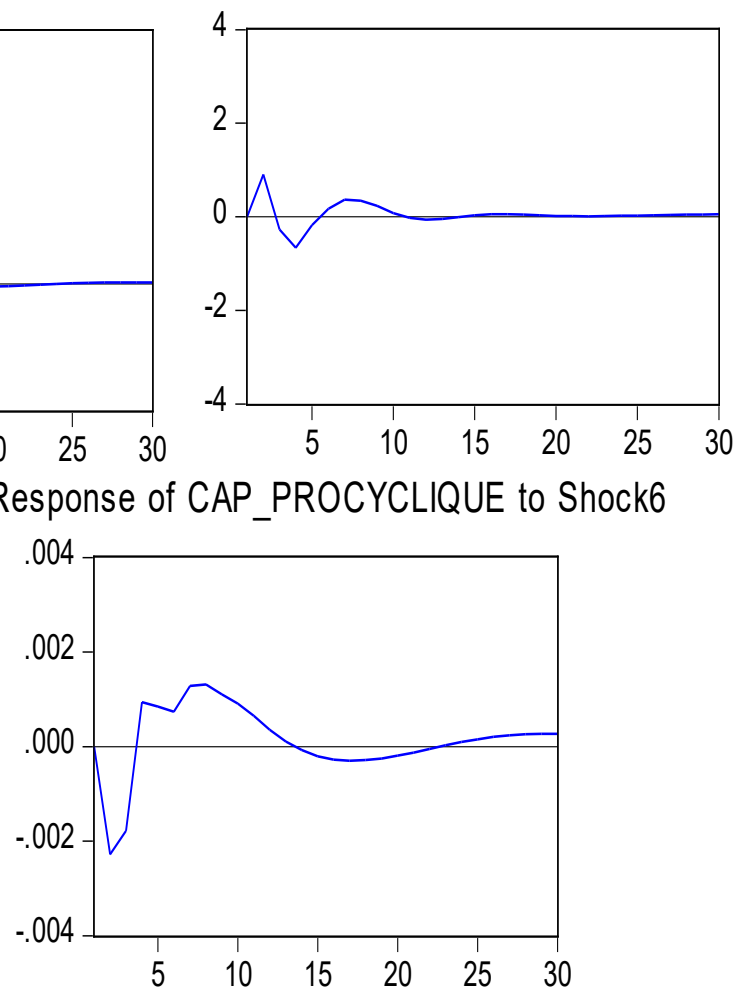
Does the Procyclicality of Capital Requirements Affect Financial Stability in Cemac?

RCA
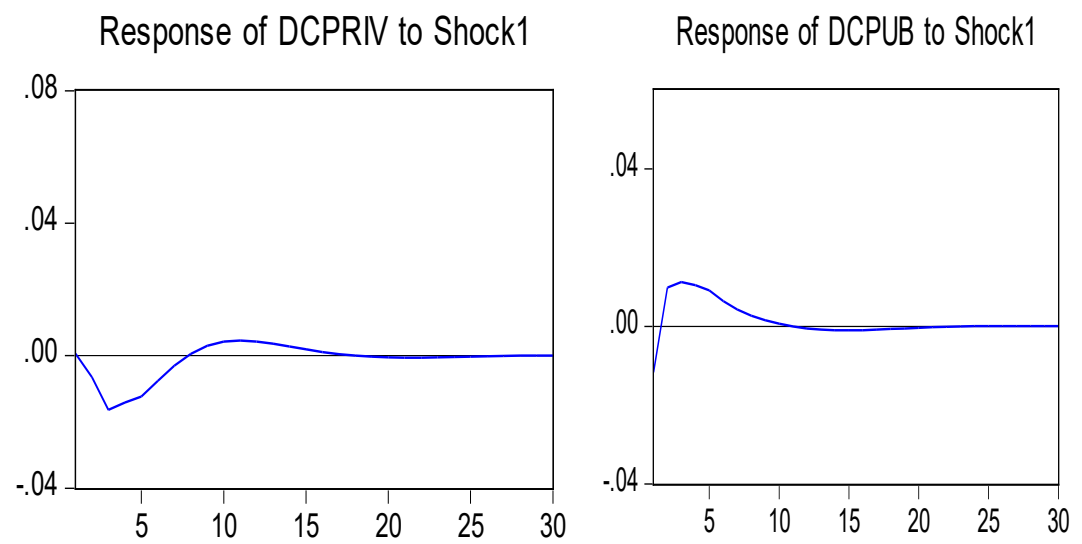

Response of DINFL to Shock1

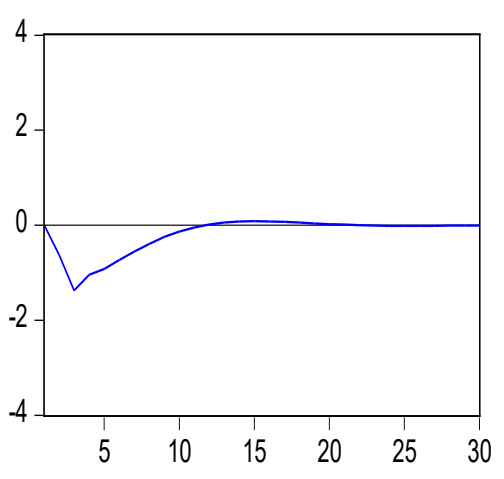

Response of CAP_PROCYCLIQUE to Shock4 Response of CAP_PROCYCLIQUE to Shock6
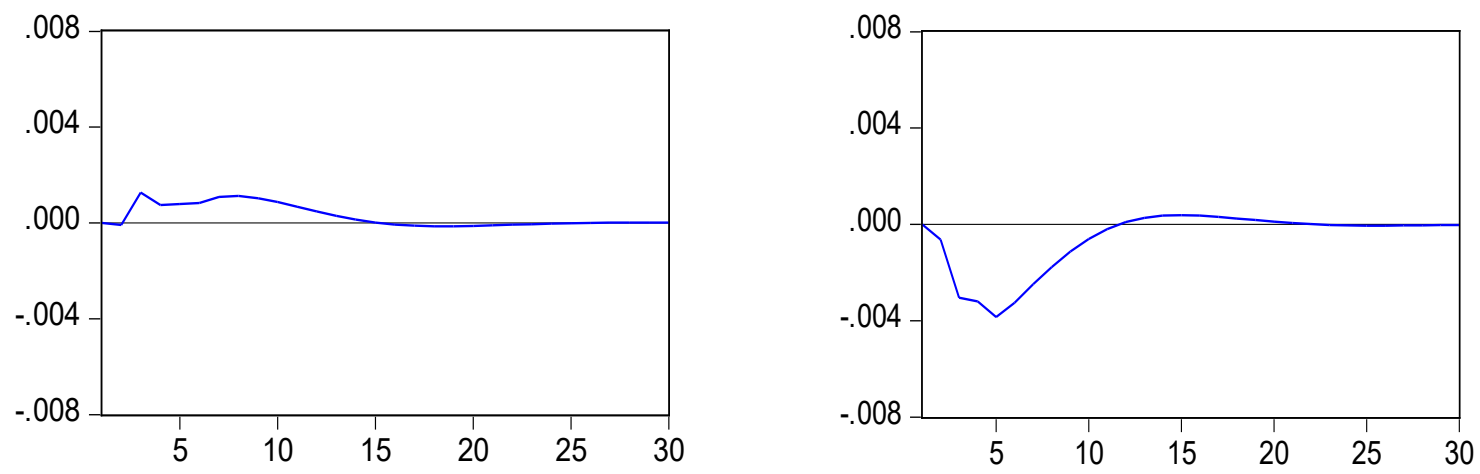

\section{Congo}

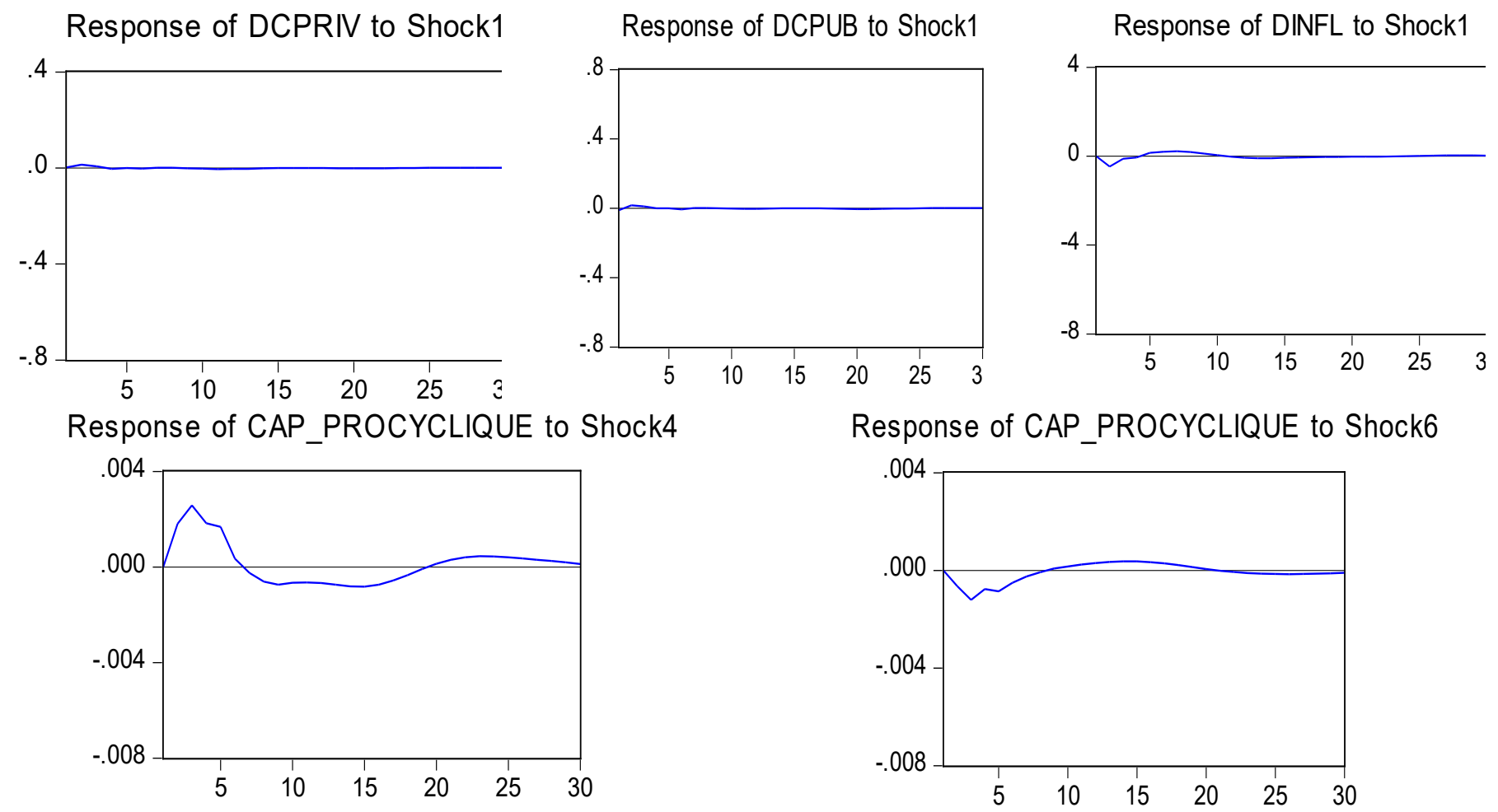


Djimoudjiel Djekonbé, Ningaye Paul, and Nafé Daba

\section{Gabon}
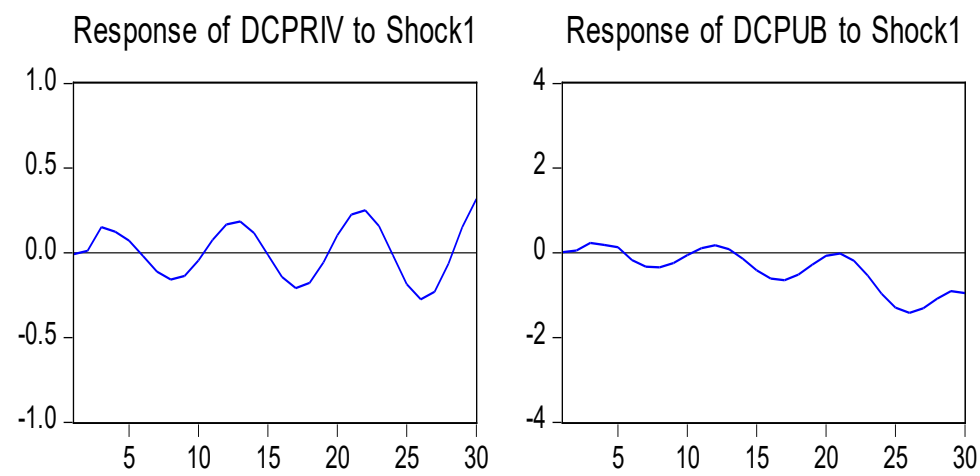

Response of DINFL to Shock1

Response of CAP_PROCYCLIQUE to Shock6

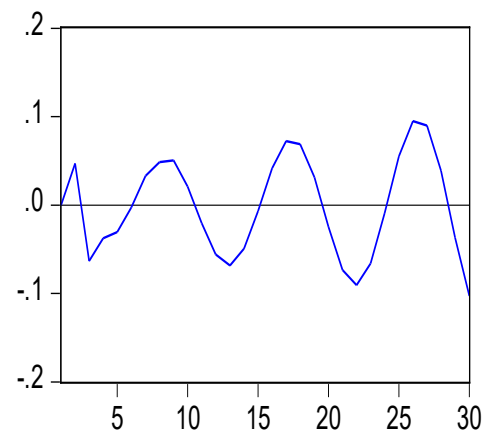

Response of CAP_PROCYCLIQUE to Shock4
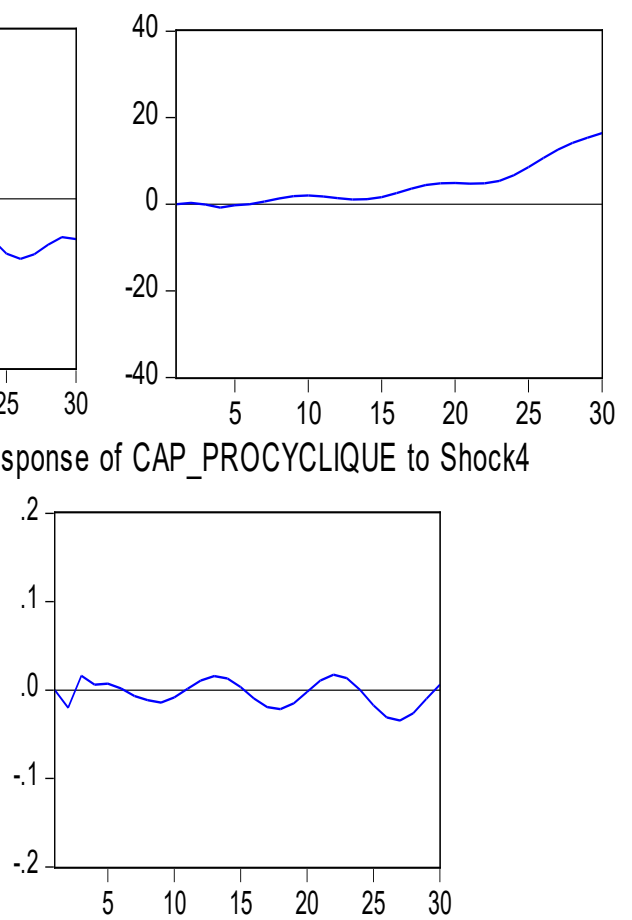

\section{Guinée Equatoriale}
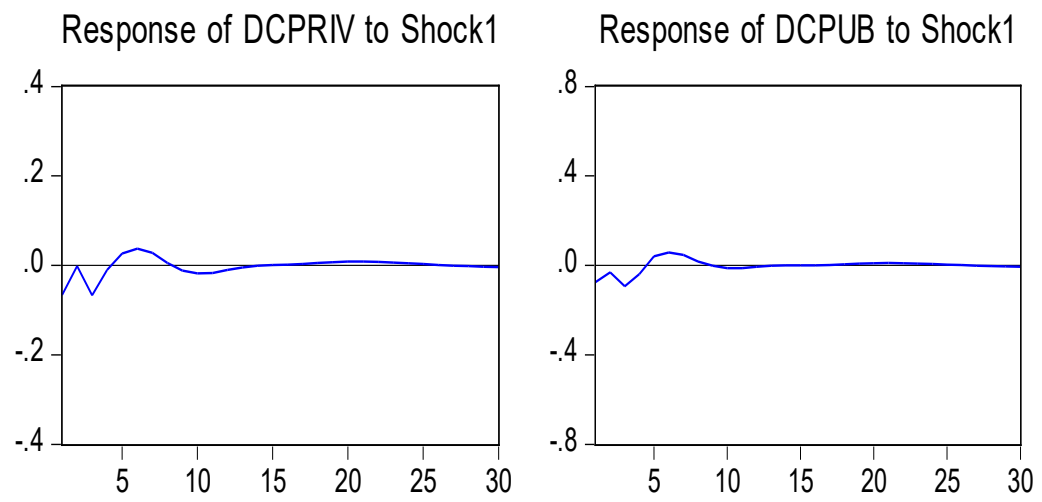

Response of DINFL to Shock1

Response of CAP_PROCYCLIQUE to Shock4

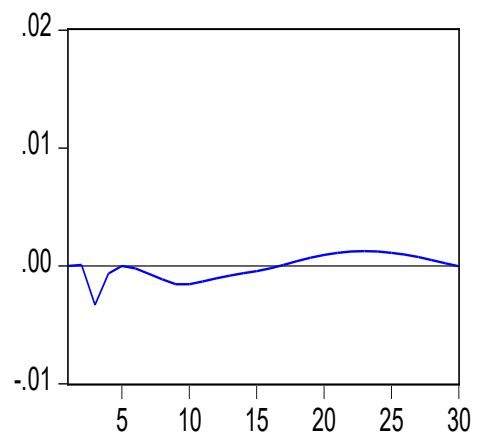

Response of CAP_PROCYCLIQUE to Shock6
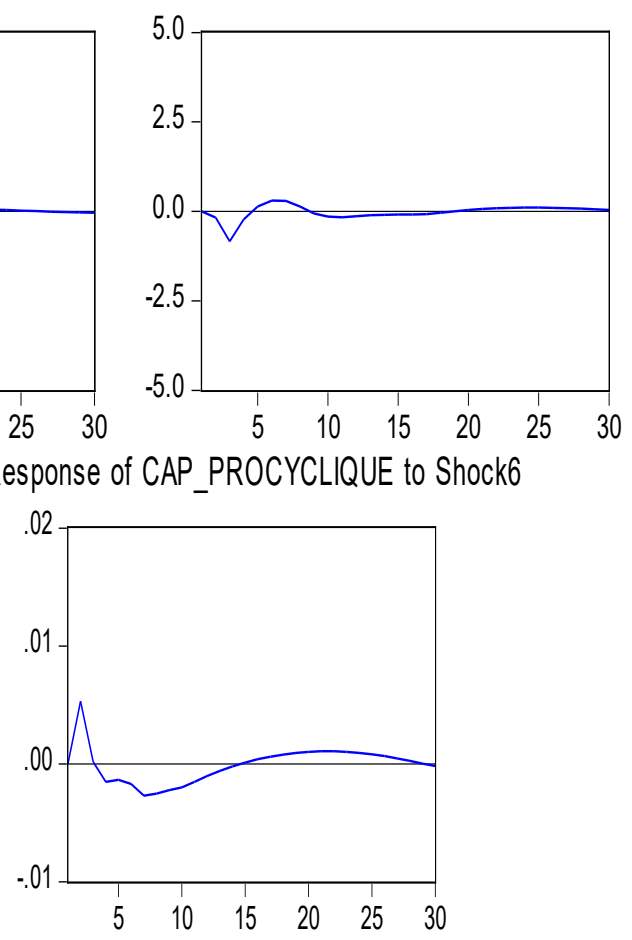
Does the Procyclicality of Capital Requirements Affect Financial Stability in Cemac?

\section{Tchad}
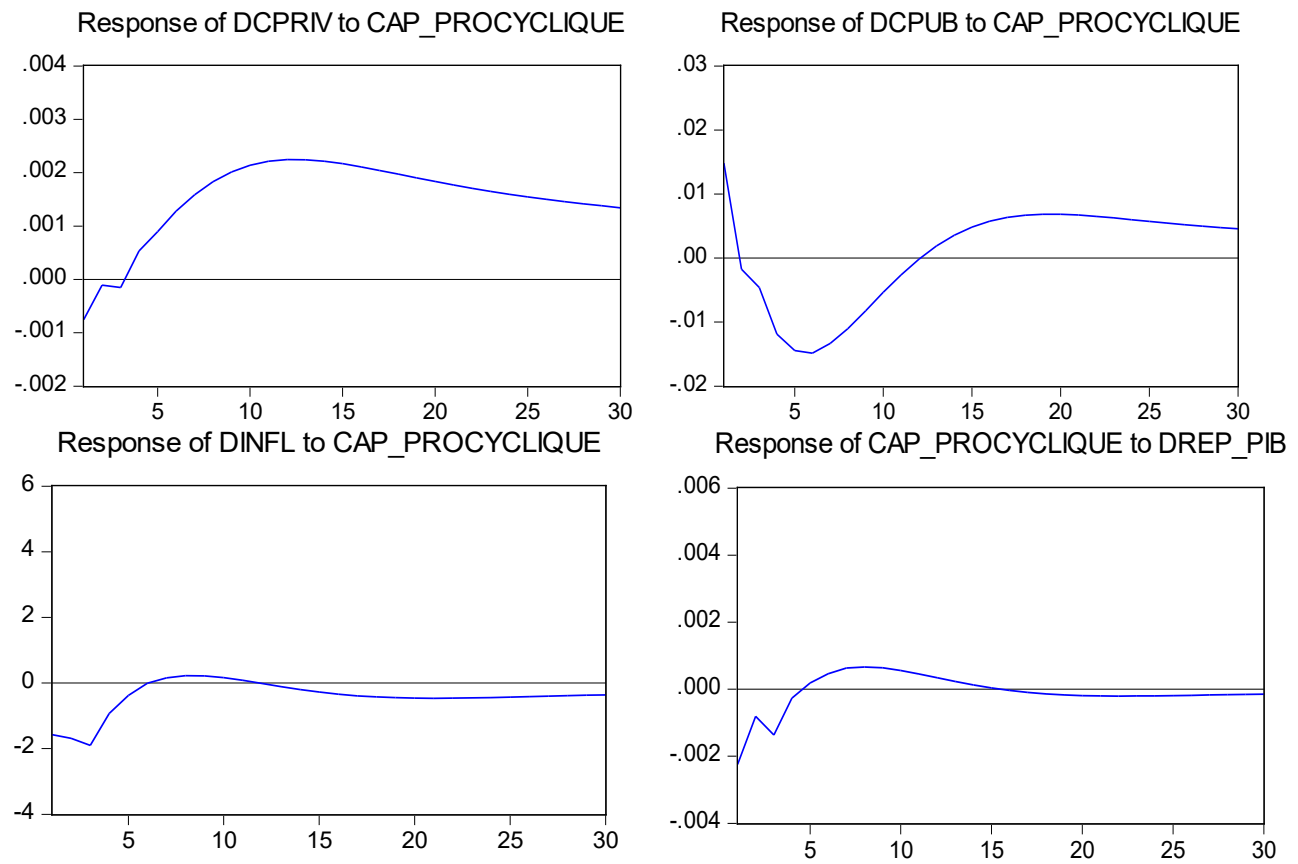

Appendix 6: Pro or contracyclicality of bank capital in CEMAC countries
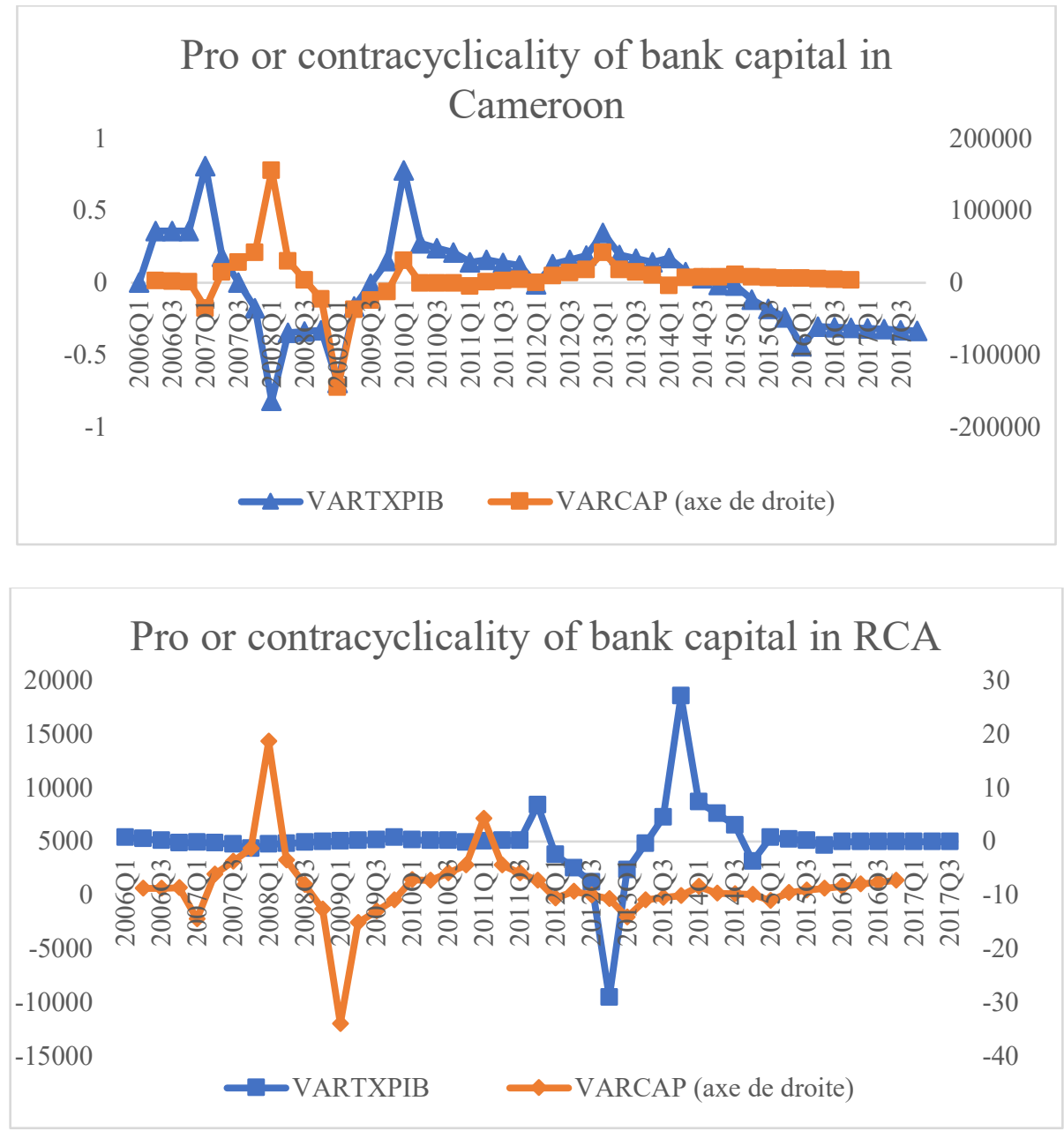
Djimoudjiel Djekonbé, Ningaye Paul, and Nafé Daba
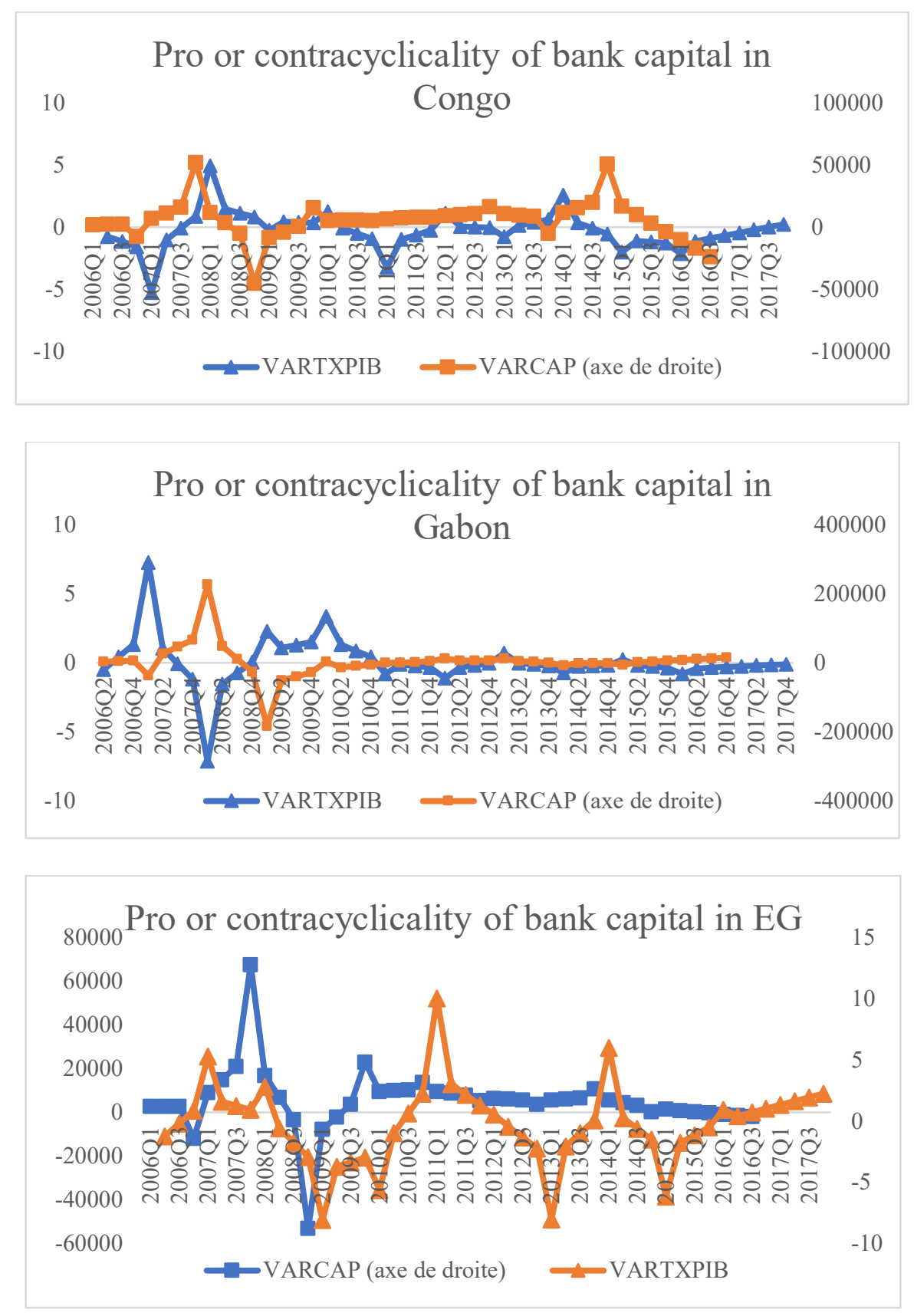

\section{Source: Authors}

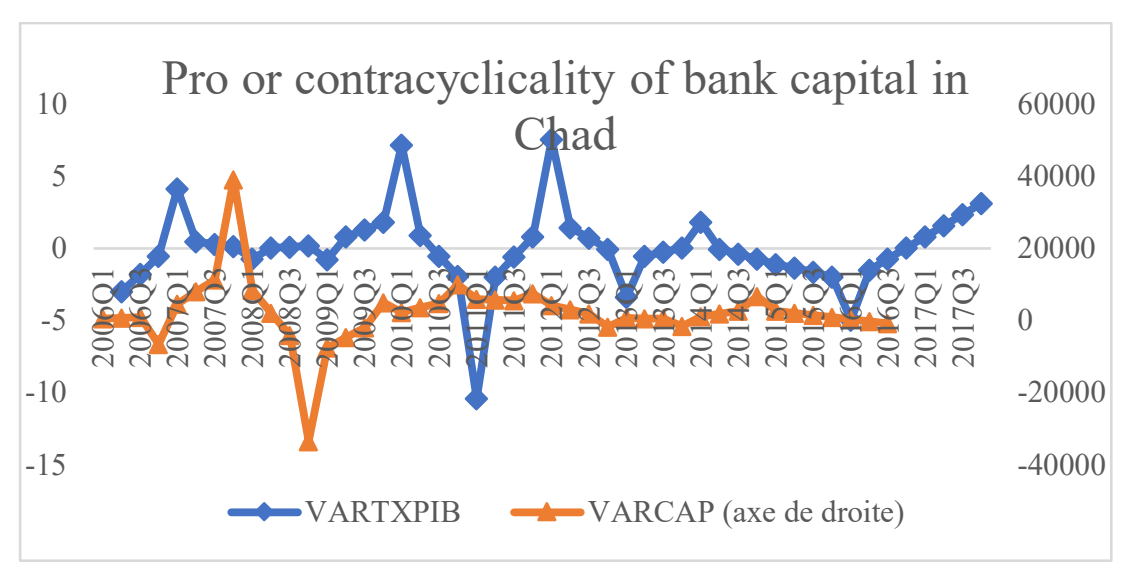


Does the Procyclicality of Capital Requirements Affect Financial Stability in Cemac?

\section{SOURCES OF FUNDING}

This research received no specific grant from any funding agency in the public, commercial, or not-for-profit sectors.

\section{CONFLICT OF INTEREST}

The author have declared that no competing interests exist.

\section{ACKNOWLEDGMENT}

None.

\section{REFERENCES}

[1] Arif-Pasha, M., \& Kswamy, T. (2012). Basel II norms with spatial emphasis on capital adequacy ratio of indian banks. Journal of MP Birla Istitute of Managment, 23-40.

[2] Barajas, A., Chami, R., Cosimano, T., \& Martínez-Peria, M. (2004). Did the Basel Accord Cause a Credit Slowdown in Latin America?. Economía, Vol. 5, No. 1, 135-182.

[3] BEAC. (2016). Situation of the CEMAC banking system as at 31 December 2016. Yaoundé: Bank of Central African States (BEAC).

[4] BEAC. (2018). Monetary Policy Report. Yaoundé: BEAC.

[5] Berenger, F., \& Teiletche, J. (2003). Basel 2 and Procyclicality. Financial Economics Review, No. 73, 227250.

[6] Bernanke, B., \& Blinder, A. (1992). The federal funds rate and the channels of monetary transmission. American economic review, No 82, 901-921.

[7] Bernanke, B., \& Gertler, M. (1995). Inside the Black Box: The Credit Channel of Monetary Policy Transmission. The Journal of Economic Perspectives, vol 9, No 4, 27-48.

[8] Bharath, S., \& Shumway, T. (2008). Forecasting Default with the Merton Distance to Default Model. The Review of Financial Studies, Vol. 21, No. 3, 1339-1369.

[9] Bikai , J., \& Essiane , P.-N. D. (2017). Monetary Policy, Monetary Stability and Economic Growth in CEMAC: A Bayesian SVAR Approach. BEAC Working Paper, No. 8.

[10] Caporale, T., \& McKiernan, B. (1999). Monetary Policy Shocks and Interest Rates: Further Evidence on the Liquidity Effect. Weltwirtschaftliches Archiv, Bd. 135, H. 2, 306-316.

[11] Chandrasekhar, C. (2008). Beyond basel for banking regulation. Economic and political weekly, Vol 43, No 50, 8-9.

[12] COBAC. (2010). Annual Report: Fiscal Year 2010. COBAC.

[13] Das, A. (2002). Risk and Productivity Change of Public Sector Banks. Economic and Political Weekly, Vol. 37, No. 5, 437-448.

[14] Diamond, D. W. (1984). Financial intermediation and delegated monitoring. Review of economic studies, $393-$ 414.

[15] Diamond, D., \& Dybvig, P. (2000). Bank Runs, Deposit Insurance, and Liquidity. Federal Reserve Bank of Minneapolis Quarterly Review, Vol. 24, No. 1, 14-23.

[16] Djimoudjiel, D. (2018). Banking capitalization and financial development in Chad: the comparative effect of the banking process. The Economic research guardian, Vol 8, No 2, 65-77.

[17] Elbourne, A., \& Haan, j. (2009). Modeling monetary policy transmission in acceding countries: Vector autoregression vesus structural vector autoregression. Emerging Markets Finance \& Trade, Vol. 45, No. 2, 420.

[18] Estrella, A. (2004). The cyclical behavior of optimal bank capital. Journal of Banking \& Finance, No 28, 14691498.

[19] Facchini, F. (2010). 2007: A systemic crisis? Revue d'économie financière, No. 97, 155-183.

[20] Fernández, A. I., González, F., \& Suárez, N. (2012). How Bank Market Concentration, Regulation, and Institutions Shape the Real Effects of Banking Crises. International Money and Finance, No 33, 19-40. 
[21] Goodhart, C., Boris, H., \& Segovia, M. (2004). Bank regulation and macroeconomic fluctuations. Oxford Review of Economic Policy, Vol. 20, No. 4, 591-615.

[22] Hanson, S., Kashyap, A., \& Stein, J. (2011). A Macroprudential Approach to Financial Regulation. The Journal of Economic Perspectives,Vol. 25, No. 1, 3-28.

[23] Illing , M., \& Paulin, G. (2005). Basel II and the Cyclicality of Bank Capital. Canadian Public Policy, Vol. 31, No. 2, 161-180.

[24] Majnoni, G., Powell, A., Correa, P., \& Brock, P. (2005). Reforming Bank Capital Requirements:

[25] Implications of Basel II for Latin American Countries. Economia, Vol. 5, No. 2, 105-149.

[26] Mishkin, F. (2010). Money, Banking and Financial Markets. Paris: Pearson education.

[27] Mitchell, W. (1998). the impact of risk-based capital requirements on the indigenous banks of the eastern caribbean central bank area. Savings and Development, Vol. 22, No. 2, 181-202.

[28] Miyao, R. (2002). The Effects of Monetary Policy in Japan. Journal of Money, Credit and Banking, Vol. 34, No. 2, 376-392.

[29] Mojon, B. (1996). Capital Adequacy Ratio and Credit Cycle. Revue d'économie politique, Issues on financial intermediation and monetary policy, 106(4), 727-743.

[30] NachaneD, \& Ghosh, S. (2001). Risk-Based Standards, Portfolio Risk and Bank Capital: An Econometric Study. Economic and Political Weekly, Vol. 36, No. 10 , 871-876.

[31] Nhamias, L. (2013). UK banks face the test of a new regulatory paradigm and economic uncertainty. Financial Economics Review, No. 111, 83-105.

[32] Ouédraogo, S. (2014). Impact de la réglementation bancaire sur le comportement des banques de l'Union Economique et Monétaire Ouest Africaine (UEMOA). Burkina Faso: PhD thesis, University of Ouaga II.

[33] Pujal, A. (2003). From Cooke to Basel II. Revue d'économie financière, No. 73, 65-76.

[34] Rabell, E. C., Jackson, P., \& Tsomocos, D. P. (2005). Procyclicality and the New Basel Accord: Banks' Choice of Loan Rating System. Economic Theory, Vol 26, No. 3, 537-557.

[35] Rajan, R. S., \& Parulkar, M. (2008). Real sector shocks and monetary policy responses in a financially vulnerable emerging economy. Emerging Markets Finance \& Trade, Vol. 44, No. 3, 21-33.

[36] Repullo, R., Saurina, J., Trucharte, C., \& Ravn, M. (2010). Mitigating the procyclicality of Basel II. Economic Policy, Vol. 25, No. 64, 659-702.

[37] Reza, S. (2011). Macroprudential approach to banking regulation: perspectives of selected asian central banks. ADBI working paper series, No 325, Asian Development Bank Institute, Tokyo.

[38] Rochet, J. (2008). The future of prudential regulation. Toulouse School of Economics.

[39] Shrieves, R., \& Dahl, D. (1992). The relationship between risk and capital in commercial banks. Journal of Banking and Finance, No 2, Vol16, 439-57.

[40] Tery, C. (2009). The new basel capital accord: A major advance at the turbulent time. A Journal of Policy Analysis and Reform, Vol 16, No 1, 25-43.

[41] Yellen, J. (2011). Macroprudential Supervision and Monetary Policy in the Post-crisis World. Business Economics, Vol. 46, No. 1, 3-12.

[42] Zeid, S. (2011). International Convergence of Capital Standards: What Effects on Emerging Market Banks?. Economic Review, Vol. 62, No. 4, 687-715. 